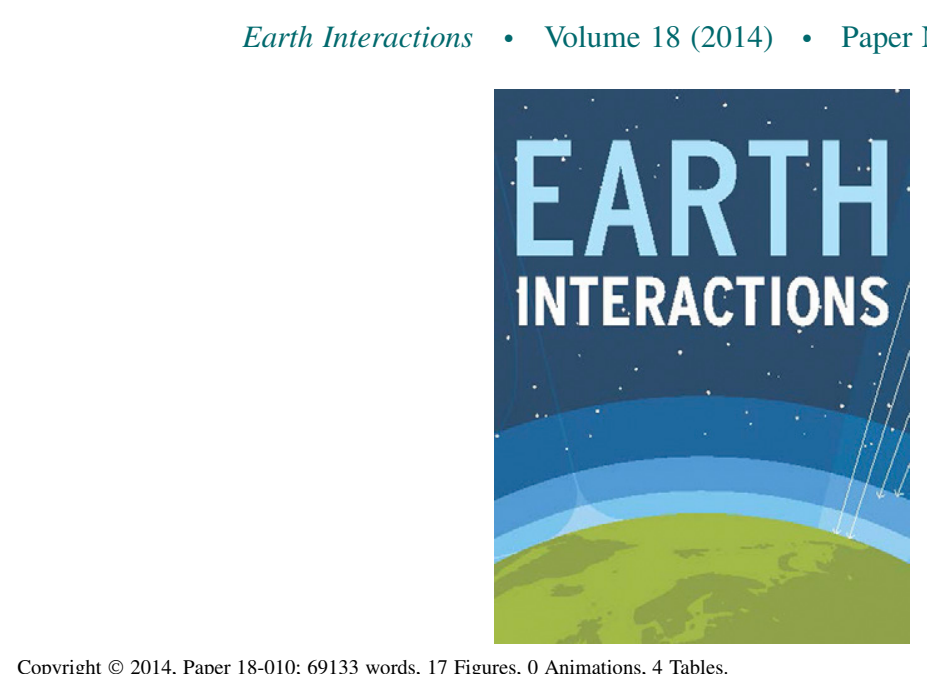

Copyright (c) 2014, Paper 18-010; 69133 words, 17 Figures, 0 Animations, 4 Tables.

http://EarthInteractions.org

\title{
Land Surface Heterogeneity Signature in Tornado Climatology? An Illustrative Analysis over Indiana, 1950-2012*
}

\section{Olivia Kellner}

Department of Earth, Atmospheric, and Planetary Sciences, and Indiana State Climate Office, Purdue University, West Lafayette, Indiana

\section{Dev Niyogi ${ }^{+}$}

Department of Agronomy, and Department of Earth, Atmospheric, and Planetary Sciences, and Indiana State Climate Office, Purdue University, West Lafayette, Indiana

Received 10 July 2013; accepted 25 November 2013

\begin{abstract}
Land surface heterogeneity affects mesoscale interactions, including the evolution of severe convection. However, its contribution to tornadogenesis is not well known. Indiana is selected as an example to present an assessment of documented tornadoes and land surface heterogeneity to better understand the spatial distribution of tornadoes. This assessment is developed using a GIS framework
\end{abstract}

* Supplemental information related to this paper is available at the Journals Online website: http://dx.doi.org/10.1175/2013EI000548.s1.

${ }^{+}$Corresponding author address: Dev Niyogi, Purdue University, Indiana State Climate Office, Lily 2-420, 915 W. State St., West Lafayette, IN 47907.

E-mail address: dniyogi@purdue.edu 
Earth Interactions - Volume 18 (2014) - Paper No. 10 • Page 2

taking data from 1950 to 2012 and investigates the following topics: temporal analysis, effect of ENSO, antecedent rainfall linkages, population density, land use/ land cover, and topography, placing them in the context of land surface heterogeneity.

Spatial analysis of tornado touchdown locations reveals several spatial relationships with regard to cities, population density, land-use classification, and topography. A total of $61 \%$ of F0-F5 tornadoes and $43 \%$ of F0-F5 tornadoes in Indiana have touched down within $1 \mathrm{~km}$ of urban land use and land area classified as forest, respectively, suggesting the possible role of land-use surface roughness on tornado occurrences. The correlation of tornado touchdown points to population density suggests a moderate to strong relationship. A temporal analysis of tornado days shows favored time of day, months, seasons, and active tornado years. Tornado days for 1950-2012 are compared to antecedent rainfall and ENSO phases, which both show no discernible relationship with the average number of annual tornado days. Analysis of tornado touchdowns and topography does not indicate any strong relationship between tornado touchdowns and elevation. Results suggest a possible signature of land surface heterogeneity - particularly that around urban and forested land cover-in tornado climatology.

KEYWORDS: Tornado climatology; Tornadoes and population; Storm reports; Tornado day; Land surface interactions; Land surface heterogeneity; Urban storm interactions

\section{Introduction}

Efforts to identify active regions of severe weather and tornado climatology spanning different spatial and temporal scales has been completed over the last several decades (e.g., Agee 1970; Pryor and Kurzhal 1997; Concannon et al. 2000; Brooks et al. 2003a; Brooks et al. 2003b; Schneider et al. 2004; Ashley 2007; Kis and Straka 2010; Dixon et al. 2011). Specific investigations of tornadoes as related to teleconnection patterns such as the El Niño-Southern Oscillation (Agee and ZurnBirkhimer 1998; Rhome et al. 2000; Nunn and DeGaetano 2004; Mayes et al. 2007; Cook and Schaefer 2008) and synoptic features (Rose et al. 2004) have been completed as well. Research investigating tornadoes and population notes a possible feedback between higher tornado frequencies in areas of higher population and an increase in tornado reports with a surge in storm spotters in the late 1980s and early 1990s (Changnon 1982; Twisdale 1982; Tescon et al. 1983; McCarthy and Schaefer 2004). Of recent concern to operational meteorologists, the media, and county emergency managers is the desensitization of the public to tornado warnings. A recent 5 -yr climatology of tornado false alarm rates shows how difficult it still remains to accurately detect and warn for a tornado (Brotzge et al. 2011), providing more persuasive evidence of the need to document, study, and consider local features for the possibility of anomalous trends in tornado frequencies and distributions.

There is growing body of literature (for a review, see Pielke et al. 2011) indicating land surface heterogeneity can impact the evolution of mesoscale convective systems. As discussed for instance in Holt et al. (Holt et al. 2006) and Niyogi et al. (Niyogi et al. 2006), landscape heterogeneity may alter the mesoscale convergence and energetics of the storm system from the microscale to the mesoscale. Studies such as Kellner et al. (Kellner et al. 2012) and Bozeman et al. (Bozeman et al. 2012) suggest possible largerscale feedback of the land heterogeneity altering the storm track and sustenance of even tropical systems. Indeed, a number of factors need to work in concert with each 
Earth Interactions - Volume 18 (2014) • Paper No. 10 • Page 3

other to lead to the evolution of a thunderstorm into a tornadic thunderstorm, and it is difficult to attribute surface processes as being a dominant factor. However, as discussed in Shepherd et al. (Shepherd et al. 2009), the intent of this climatology and spatial assessment is to provide forecasters with additional local environmental factors they can consider in the forecast process as they seek to develop tornado watches or as they seek to issue a tornado warning on a storm. To that end, one additional goal of this assessment is to evaluate if there is any potential signature of landscape heterogeneity on tornado climatology, which until this time has been poorly studied.

Observations of tornadoes occurred long before national databases began keeping official records (1950) with the first photographed tornado documented in August 1884 approximately 20 miles southwest of Howard, South Dakota (Ross et al. 2011). The United States is well known for its "Tornado Alley," a region primarily covering Texas, Oklahoma, Kansas, Nebraska, southwestern Iowa, eastern South Dakota, and eastern Colorado (Edwards 2011) that has an increased risk for strong and violent tornadoes (as adapted by Concannon et al. 2000). However, the Midwest (defined here as Wisconsin, Michigan, Illinois, Indiana, Kentucky, and Ohio) sees a fair amount of tornadoes, such as the 1965 Palm Sunday outbreak and the 1974 super outbreak. In recent years, some national tornado climatologies have identified the Midwest as a branch or corridor extending from Tornado Alley, where an increase in tornado frequency is documented, more specifically through Illinois and into Indiana, especially when reviewed for strong (F2-F5) tornadoes (Agee and Zurn-Birkhimer 1998; Concannon et al. 2000; Rauber et al. 2005; Ashley 2007; Dixon et al. 2011).

Tornadoes form in many environments and form with different types of convection, which are all observed in Indiana: quasi-linear convective system (QLCS) tornadoes (50\% of Indiana's reported tornadoes; e.g., Trapp et al. 2005), supercell tornadoes, low-top mini supercell tornadoes, landspout tornadoes, and gustnadoes, as well as tornado outbreaks (Agee and Jones 2009). The severe weather and tornadic environment on the Great Plains, by contrast, is more commonly impacted discrete cells/supercells (Smith et al. 2012). While national tornado climatologies show an increased frequency of tornadoes over Indiana, only two other climatologies for the state have been completed (Agee 1970; Pryor and Kurzhal 1997). This temporal and spatial climatology serves to complement these past studies, adding an additional decade of tornado data to the most current climatology for the state of Indiana (Pryor and Kurzhal 1997). The current sample size of annual tornado data and the amount of errors in the tornado databases the United States limits the scientific community's ability to decipher significant trends (e.g., Doswell 2007; Kunkel et al. 2013). Hence, the scientific community is encouraged to update severe weather and tornado reports to increase the sample size and make note of any evolving trends, especially as the United States continues to experience climate variability.

This climatology considers several variables instead of focusing on one: temporal analysis; ENSO; extreme climate events; population; and spatial distribution in relation to land surface characteristics such as land-use/land-cover (LULC) boundaries, topography, and surface roughness. The impact of LULC/land surface heterogeneity on mesoscale circulations and boundary layer destabilization has been studied for years (Clark and Arritt 1995; Pielke 2001; Mahmood et al. 2012) with tornadic environments analyzed as discussed in Cheresnick and Basara (Cheresnick and Basara 2005). It is studies such as these on land surface feedbacks to the storm environment that motivates this climatology to investigate the spatial distribution of tornado 
Earth Interactions - Volume 18 (2014) • Paper No. 10 • Page 4

touchdown points in Indiana. Indiana is more specifically chosen for the following reasons: 1) uncertainties in tornado climatology datasets and the authors' familiarity with the state's weather and climate; 2) it is a land-locked state (except for those counties along Lake Michigan, which experience localized climate feedbacks), providing for local mesoscale feedbacks to develop across the state between land-cover and land-use transition zones instead of land and water boundaries; 3) a vast majority of tornadoes in Indiana are weak [i.e., enhanced Fujita scale 0 (EF0) to EF1] and are not driven by classic supercell dynamics: this suggests surface feedbacks can have a larger impact on surface heat and moisture fluxes that may interact with convective processes; and 4) the urban climate appears to influence or modify thunderstorms and rainfall patterns (e.g., Bornstein and Lin 2000; Niyogi et al. 2011), of which Indiana has sharply contrasting urban locales surrounded by agriculture land use.

\section{Methodology}

The geospatial dataset developed for this Indiana tornado climatology is obtained and developed from the Storm Prediction Center (SPC) Severe Geographic Information System (SVRGIS) database. "Tornado" and "states" shapefiles (the tornado shapefile is for tornado touchdown points in 1950-2011; 2012 is still considered preliminary at the time of this study) are downloaded and queried to extract and create shapefiles for the Midwest (Ohio, Indiana, Kentucky, Michigan, and Illinois). The tornado shapefile is a point shapefile that plots the starting latitude and longitude of a tornado (touchdown location). A 2010 U.S. Census population density raster file is also obtained from the SPC SVRGIS website (http://www.spc.noaa.gov/gis/svrgis/) for population analysis.

Multiple queries are completed on the tornado shapefile from the SVRGIS webpage to create a Midwest F0-F5 tornadoes shapefile to use for analysis. The ArcGIS 10.1 spatial analyst tool for point density is applied to the point shapefile dataset to create a spatially interpolated shapefile that shows the highest and lowest locations of tornado touchdown point density in Indiana (Figure 1). The touchdown point density file is a spatial plot of the calculated magnitude per unit area (square kilometers) of point features (tornado touchdown points) that fall within a neighborhood (defined as $28000 \mathrm{~km}^{2}$, a default suggested value by the spatial interpolation algorithm within the GIS based on the size/area of the map data frame) around each cell. Simply put, it is the total number of points that fall within the specified neighborhood around a cell divided by the area of the neighborhood. "Natural breaks" is used to compute the density histogram with 18 classes. Natural breaks is a method of classification that seeks to find natural classes within the dataset histogram by optimally reducing the variance within classes while maximizing the variance between classes (de Smith et al. 2013). The tornado touchdown density raster file is smoothed with a bilinear interpolation filter for aesthetic appeal. The F scale is used instead of the EF scale because a majority of tornadoes in the NCDC database and all of the tornadoes in the SPC SVR GIS files are classified with F-scale rankings. A Midwest tornado shapefile is used instead of an Indiana shapefile in order to provide continuity to the density map across state borders. The spatial density distribution maps represent a general spatial distribution pattern, not an exact density distribution pattern. This results from the use of several different map projections for the completion of this climatology that may result in plotting errors. 


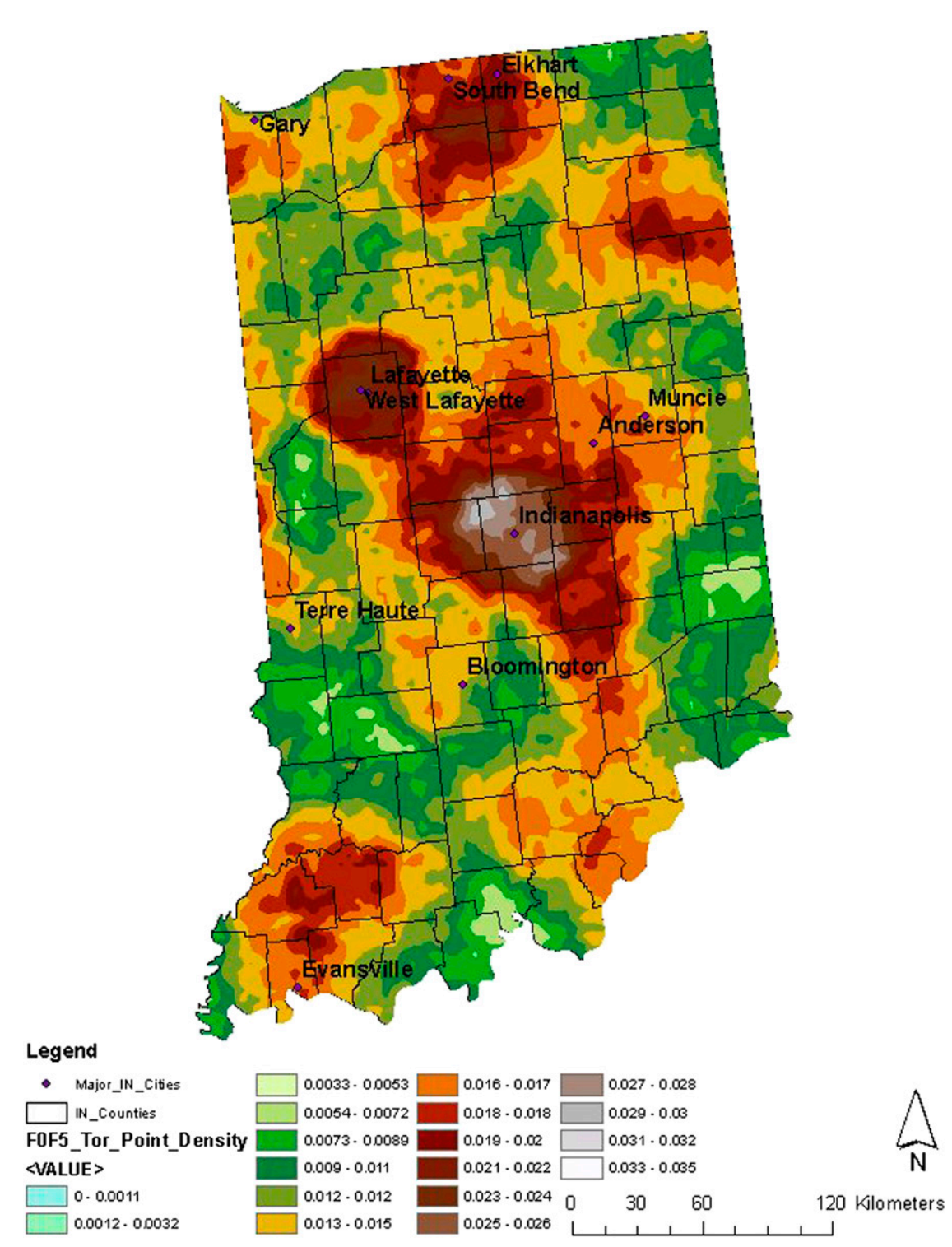

Figure 1. Tornado touchdown point density file for all tornadoes (F0-F5) from 1950 to 2011.

\section{Discussion of findings}

\subsection{Temporal data}

\subsubsection{Tornado day and daily temporal distributions}

A tornado day climatology for 1950-2012 is completed for Indiana for all tornadoes $(\mathrm{F} 0-\mathrm{F} 5)$, weak tornadoes $(\mathrm{F} 0-\mathrm{F} 1)$, and strong tornadoes $(\mathrm{F} 2-\mathrm{F} 5)$. A tornado day in this study is developed from the definition proposed in Changnon and Schickedanz (Changnon and Schickedanz 1969) and equates a tornado day as a day 


$$
\text { Earth Interactions - Volume } 18 \text { (2014) • Paper No. } 10 \text { • Page } 6
$$

Table 1. (left) A list of the active tornado day years for all tornadoes defined by having the total number of tornado days one standard deviation (4 days) or more above the mean (9 days). (middle) A list of the active tornado day years for weak tornadoes defined as defined by having the total number of tornado days one standard deviation (4 days) or more above the mean (7 days). (right) A list of the active tornado day years for strong tornadoes defined as having the total number of tornado days one standard deviation ( 3 days) or more above the mean ( 3 days).

\begin{tabular}{|c|c|c|c|c|c|}
\hline \multicolumn{2}{|c|}{$\begin{array}{c}\text { Years one standard deviation } \\
\text { above average annual number of } \\
\text { tornado days (F0-F5) } \\
1950-2012\end{array}$} & \multicolumn{2}{|c|}{$\begin{array}{c}\text { Years one standard deviation } \\
\text { above average annual number of } \\
\text { tornado days (F0-F1) } \\
1950-2012\end{array}$} & \multicolumn{2}{|c|}{$\begin{array}{c}\text { Years one standard deviation } \\
\text { above average annual number of } \\
\text { tornado days (F2-F5) } \\
1950-2012\end{array}$} \\
\hline 1954: 20 days & 1978: 14 days & 1954: 12 days & 1996: 11 days & 1954: 11 days & 1963: 7 days \\
\hline 1961: 15 days & 1992: 14 days & 1973: 18 days & 1998: 13 days & 1956-58: 7 days & 1965: 11 days \\
\hline 1965: 19 days & 1998: 14 days & 1975: 13 days & 2003: 17 days & 1960: 6 days & 1967: 9 days \\
\hline 1973: 21 days & 2003: 17 days & 1978: 14 days & 2006: 11 days & 1961: 13 days & 1968: 6 days \\
\hline 1975: 13 days & 2011: 15 days & 1992: 13 days & $\begin{array}{l}\text { 2008: } 11 \text { days } \\
\text { 2011: } 14 \text { days }\end{array}$ & 1962: 6 days & 1980: 7 days \\
\hline
\end{tabular}

with at least one tornado report (see also Shepherd et al. 2009). This provides an idea of how many days are favorable for tornadogenesis in a given year and month across Indiana. Storm reports are not used because of a noted bias of multiple reports for the same tornado. Tornado day information for Indiana is reviewed by month in efforts to determine seasonality and spatial shifts in seasonality if any are present and by 30-yr moving average to see if tornado days in Indiana have decreased, remained the same, or increased over time. A 30-yr moving average is used to follow the time frame of a climatic normal (Arguez and Vose 2011).

The temporal distribution of tornadoes in Indiana is analyzed via tornado days and is displayed in Tables 1 and 2. Bar graphs show the hourly distribution of tornado reports for 1950-2012, indicating the most likely time of day to see a tornado as shown in Figures 2-4. The hourly distribution of tornadoes is determined via storm report data, as time of report is required to see the hourly distribution. The most active time of day for weak tornadoes in local standard time

Table 2. (left) A list of the total number of tornado days for all tornadoes (F0-F5) by month for 1950-2012. The three most active months defining Indiana's tornado season are the months of May, June, and July. (middle) A list of the total number of tornado days for weak tornadoes by month for 1950-2012. The three most active months defining Indiana's tornado season for weak tornadoes only are the months of May, June, and July. (right) A list of the total number of tornado days for strong tornadoes by month for 1950-2012. The three most active months defining Indiana's tornado season for strong tornadoes only are the months of April, May, and June.

\begin{tabular}{lrlrllllllll}
\hline \multicolumn{2}{c}{$\begin{array}{c}\text { Number of F0-F5 tornado days } \\
\text { by month, }\end{array}$ 1950-2012 } & \multicolumn{4}{c}{$\begin{array}{c}\text { Number of F0-F1 tornado days } \\
\text { by month, 1950-2012 }\end{array}$} & \multicolumn{3}{c}{$\begin{array}{c}\text { Number of F2-F5 tornado days } \\
\text { by month, 1950-2012 }\end{array}$} \\
\hline January & 10 & July & 89 & January & 8 & July & 73 & January & 4 & July & 24 \\
February & 12 & August & 49 & February & 10 & August & 36 & February & 4 & August & 14 \\
March & 35 & September & 29 & March & 26 & September & 21 & March & 22 & September & 11 \\
April & 78 & October & 20 & April & 64 & October & 16 & April & 37 & October & 8 \\
May & 104 & November & 17 & May & 84 & November & 11 & May & 30 & November & 10 \\
June & 128 & December & 6 & June & 98 & December & 3 & June & 37 & December & 4 \\
\hline
\end{tabular}




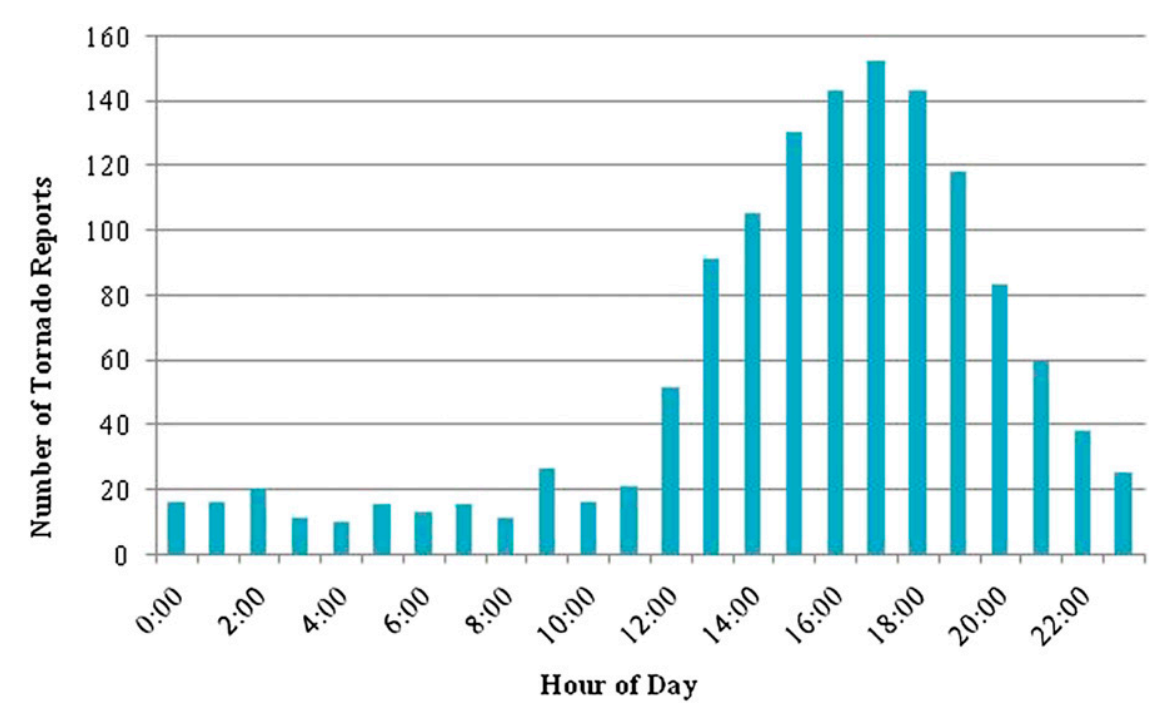

Figure 2. Hourly distribution of reported F0-F5 tornadoes in Indiana, 1950-2012.

(LST) is 1600-1900 LST; strong tornadoes have two active times, 1400-1600 LST and 1700-2000 LST; and all tornadoes are most active at 1600-2000 LST. Note that some days listed in the first column of Table 1 are also listed in the second column but not in the third column of Table 1 . This demonstrates that 1) a majority of Indiana's tornado days are more conducive to weak tornadoes and 2) all years having an F2-F5 tornado day count greater than one standard deviation above the average occurred before the implementation of the Fujita scale in 1974, except for

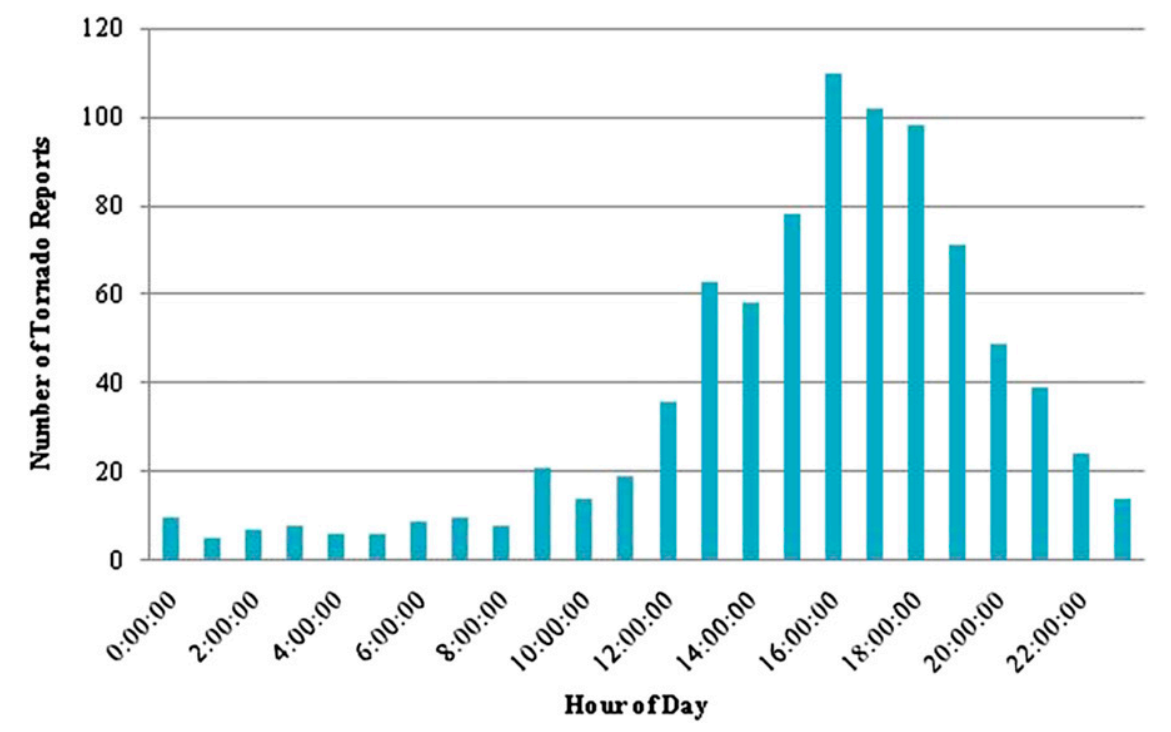

Figure 3. Hourly distribution of reported F0-F1 tornadoes in Indiana, 1950-2012. 
Earth Interactions - Volume 18 (2014) - Paper No. 10 • Page 8

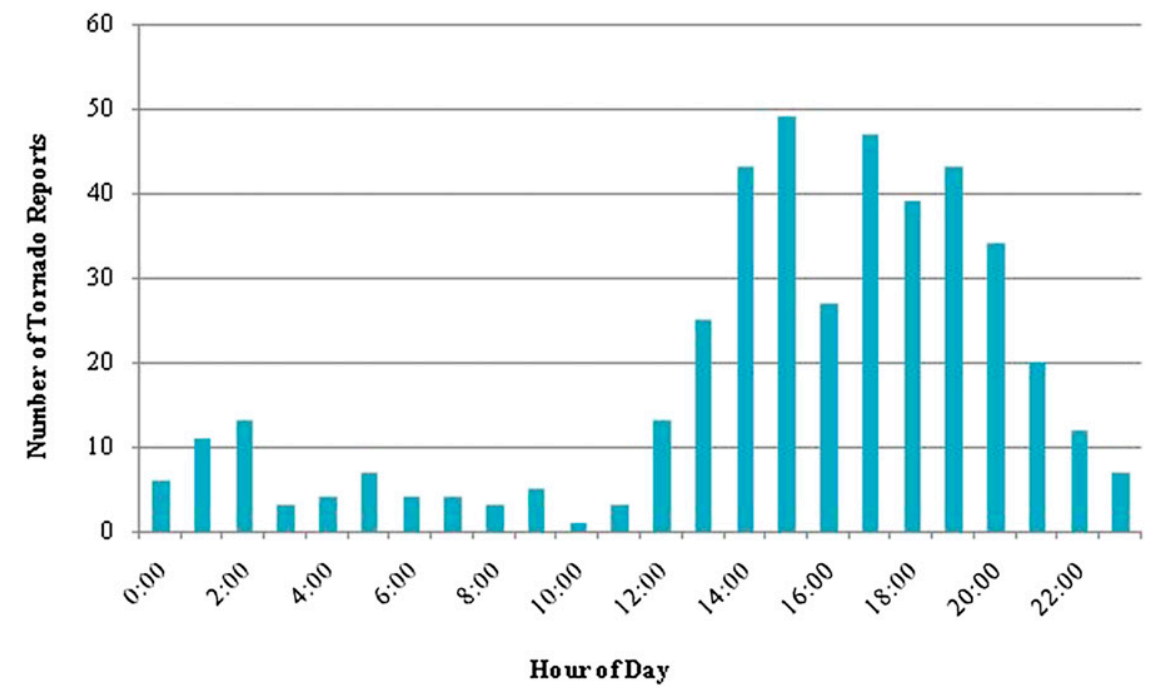

Figure 4. Hourly distribution of reported F2-F5 tornadoes in Indiana, 1950-2012.

1980. This shows the bias nature of higher F-scale rankings preceding the development of the Fujita scale (McCarthy 2003; McCarthy et al. 2006; Edwards et al. 2013).

The 30-yr moving averages for annual tornado days are computed for all tornadoes, weak tornadoes, and strong tornadoes for the study region and are listed in Table 3. Regression analysis of the 30-yr moving averages for 1950-2012 show an insignificant very slight decrease in annual tornado days for all tornadoes, a slight

Table 3. (left) A list of the 30-yr moving average number of tornado days per year for all tornadoes in 1950-2012. (middle) A list of the 30-yr moving average number of tornado days per year for weak tornadoes. (right) A list of the 30 -yr moving average number of tornado days per year for strong tornadoes. Regression analysis shows a very slight decrease ( -0.0036 slope) in F0-F5 annual average tornado days for 1950-2012; a slight increase (0.0405 slope) in F0-F1 annual average tornado days for 1950-2012; and a slight decrease ( -0.032 slope) in F2-F5 annual average tornado days for 1950-2012.

\begin{tabular}{lcc}
\hline $\begin{array}{c}\text { 30-yr moving average annual } \\
\text { number of tornado days, } \\
\text { 1950-2012 (F0-F5) }\end{array}$ & $\begin{array}{c}\text { 30-yr moving average annual } \\
\text { number of tornado days, } \\
1950-2012(\mathrm{~F} 0-\mathrm{F} 1)\end{array}$ & $\begin{array}{c}\text { 30-yr moving average annual } \\
\text { number of tornado days, } \\
1950-2012 \text { (F2-F5) }\end{array}$ \\
\hline $\begin{array}{l}\text { 11 days: } 2011 \\
\text { 10 days: } 1950-57,2000-03,\end{array}$ & $\begin{array}{c}\text { 10 days: } 2011 \\
\text { days: } 2003,2010\end{array}$ & 4 days: $1950-54$ \\
2004-09 & 9 days: $1986-2002,2004-09$ & 3 days: $1962-67,2004-05$, \\
9 days: $1958-77,1984-99$ & & $2007-08,2011$ \\
8 days: $1978-83$ & 8 days: $1963,1965,1967-85$ & 2 days: $1968-2003,2006$, \\
7 days: 2012 & 7 days: $1951-62,1964$, & $2009-10$ \\
& 1966,2012 & 1 day: 2012 \\
& 6 days: 1950 & \\
\hline
\end{tabular}


Earth Interactions - Volume 18 (2014) • Paper No. 10 • Page 9

increase in annual tornado days for weak tornadoes, and a slight decrease in annual tornado days for strong tornadoes.

The 30-yr moving averages for annual tornado days are also found by climate division. Indiana has nine climate divisions, allowing for tornado day analysis at a finer spatial scale. Annual tornado days for all tornadoes (F0-F5) for 1950-2012 are found and show a 30-yr moving average decrease in the number of annual tornado days in climate divisions 2 (north central), 3 (northeast), 4 (west central), 5 (central), and 6 (east central). Climate division 1 (northwest) has a steady 30-yr moving average with an average of 2 tornado days a year for 1950-75, 1 tornado day a year for 1976-92, and 2 tornado days a year for 1993-present. Climate divisions 7 (southwest), 8 (south central), and 9 (southeast) all show a 30-yr moving average increase in annual tornado days for 1950-2012. Climate divisions 7 and 8 see an increase in the 30-yr moving average number of annual tornado days from 1 tornado day a year to 3 days a year. Climate division 9 experiences the greatest increase in annual tornado days through time, increasing from 1 annual day on average to 4 annual days on average. Monthly analysis by climate divisions shows that the most tornado days for 1950-2012 are documented during the month of June in climate divisions $1,2,3,4,5$, and 6 , with the southernmost climate divisions peaking in monthly tornado days in May. These results highlight the scale dependency of the analysis.

\subsubsection{ENSO and extreme precipitation relationships to tornado day distribution, 1950-2012}

The 2012 drought is one example of an extreme climatic event potentially exacerbated by ENSO/La Niña. For this climatology, the oceanic Niño index (ONI) is used to determine El Niño, neutral, or La Niña years, with a minimum of 5 months of a 0.5 or greater anomaly for an El Niño or at or below the -0.5 anomaly for a La Niña. A comparison of tornado days and ENSO phase during the warm season months of April-September show no distinguishing trend in forecasting above or below active tornado seasons based on ENSO phase. Recently, Lee et al. (Lee et al. 2013) distinguish the trans-Niño index (TNI) and its relationship to the number of detrended intense tornadoes in the United States. Their findings cannot be readily compared to this study, as this climatology reviews all tornado days and Lee et al. (Lee et al. 2013) focus on tornado outbreak years. Lee et al. (Lee et al. 2013) identify 7 years from their list of top 10 extreme tornado outbreak years occurring with the transition of a La Niña to a different phase or occurring with a La Niña that persists beyond April and May while the TNI is in a positive phase: 1957, 1965, 1974, 1999, and 2008. Lee et al. (Lee et al. 2013) also identify the extreme years of 1983 and 1998 occurring with an El Niño transitioning to either a La Niña or neutral phase. Of these years, 1957, 1965, 1998, and 2008 are years listed in this tornado day climatology as years with annual tornado days one standard deviation or greater than the annual mean. Worth noting in this climatology are the years 1954, 1965, and 1973, which have some of the highest number of tornado days in

the dataset. Each of these active years coincides with a 1.3,1.6, and 1.8 swing of ENSO anomaly of El Niño to La Niña (1954), La Niña to El Niño (1965), and El Niño to La Niña (1973) when compared to the previous warm season (AprilSeptember) average anomaly. These findings, along with Lee et al. (Lee et al. 


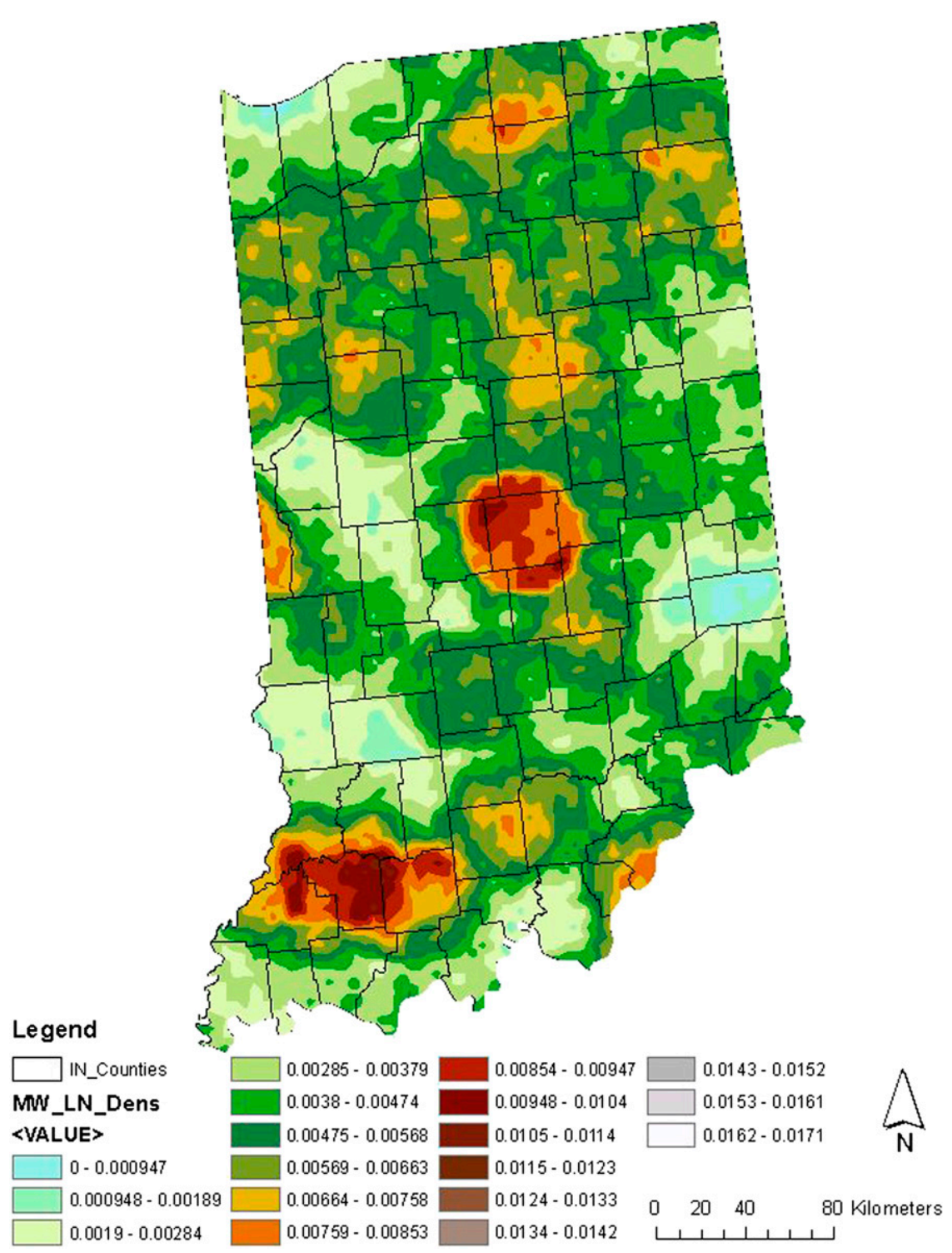

Figure 5. F0-F5 tornado touchdown point density map during La Niña years for 19502011. A La Niña year is one in which a minimum of 5 months of the ONI was at or below the -0.5 anomaly.

2013), suggest it is the rate and degree to which the ENSO phase transitions that may serve as in indicator of a more active or less active year for tornado outbreaks and tornado days. Maps of tornado touchdown point density are generated for La Niña, neutral, and El Niño years to see if any spatial shifts occur in tornado touchdown based on ENSO phase. Each phase shows spatial variation in the density of tornado touchdown points (Figures 5-7). Density difference maps between ENSO neutral touchdown points and El Niño touchdown points and between ENSO neutral touchdown points and La Niña touchdown points is provided in 


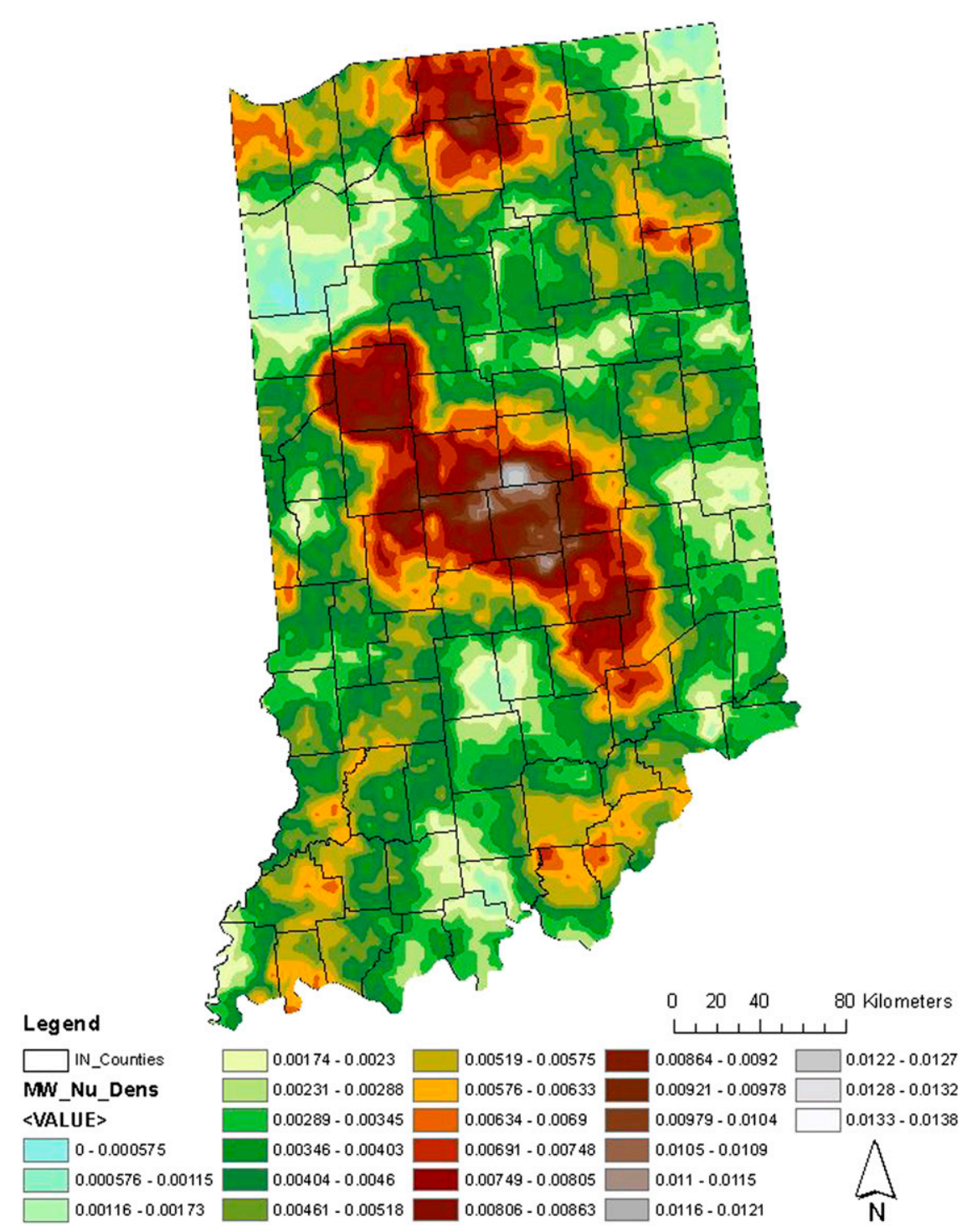

Figure 6. F0-F5 tornado touchdown point density map during ENSO neutral years for 1950-2011 (those years not classified as El Niño or La Niña).

Figures 8 and 9. A marked decrease of tornado touchdown points is seen during ENSO neutral events primarily across northwestern Indiana (climate division 1).

The 2011 tornado season is one the most active on record and is then followed by a relatively quiet season in 2012 with a majority of the country experiencing drought conditions through spring and summer. This study investigates the possibility of using drought years (85\% of normal), normal years (those not $85 \%$ below normal or $15 \%$ above normal), and climatologically wet years (15\% above normal) as indicators to expect more or less active tornado years. This process follows the wet/dry conditions and tornado occurrence as hypothesized in Shepherd et al. (Shepherd et al. 2009). Using an approach similar to Shepherd 


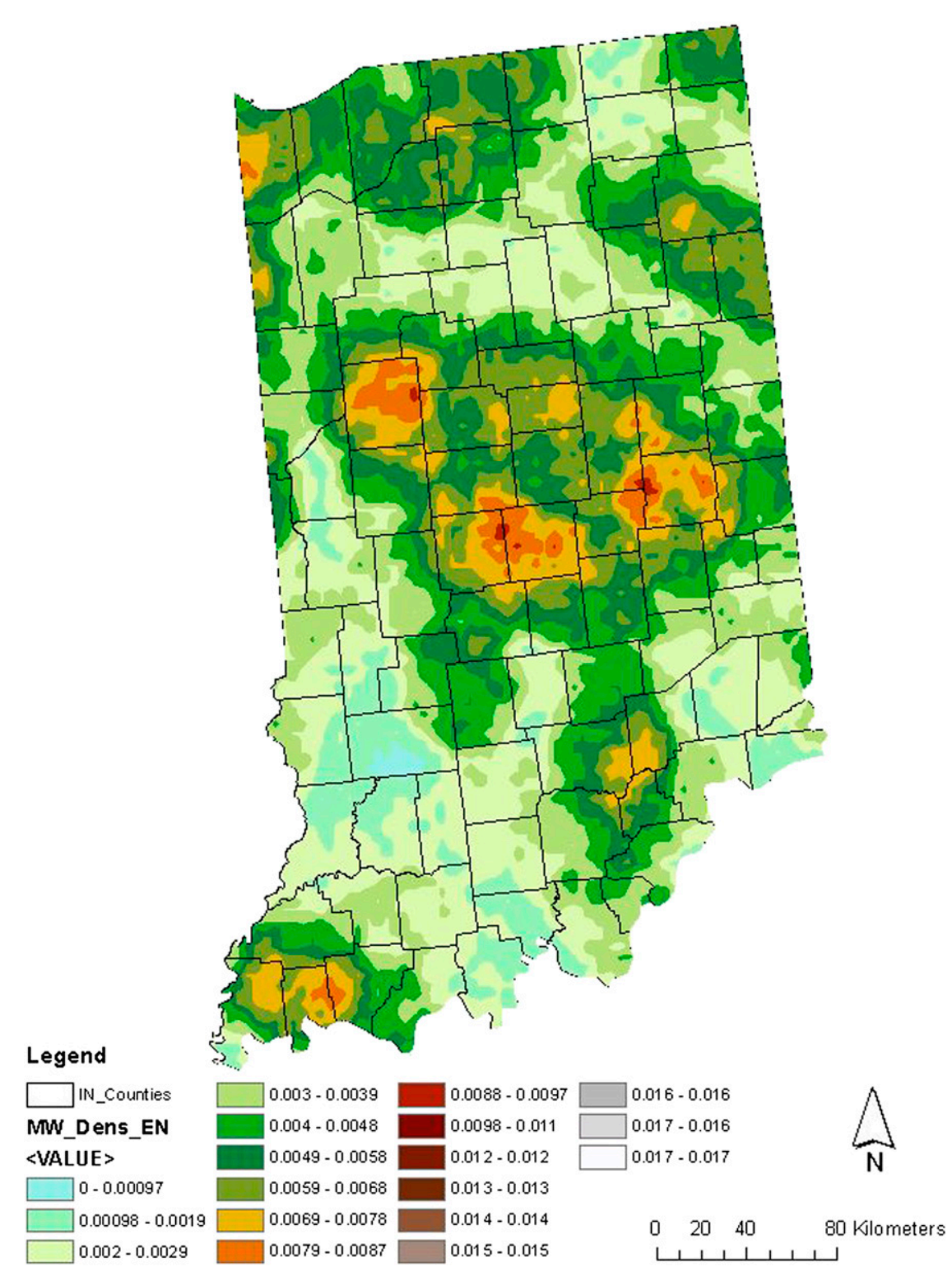

Figure 7. F0-F5 tornado touchdown point density map during El Niño years for 19502011. An El Niño year is one in which 5 months or more of a 0.5 or greater anomaly was present.

et al. (Shepherd et al. 2009), this study uses monthly state precipitation totals to determine cumulative antecedent rainfall amounts for 6 months prior (October, November, and December of previous year and January, February, and March of that year), 3 months prior (January, February, and March of that year), and 1 month prior to tornado season (March of that year) and compares total rainfall amounts to the number of tornado days for that year. Resulting data classes are as follows: 6-month drought and 6-month normal; 6-month wet and 6-month normal; 3-month drought and 3-month normal; 3-month wet and 3-month 


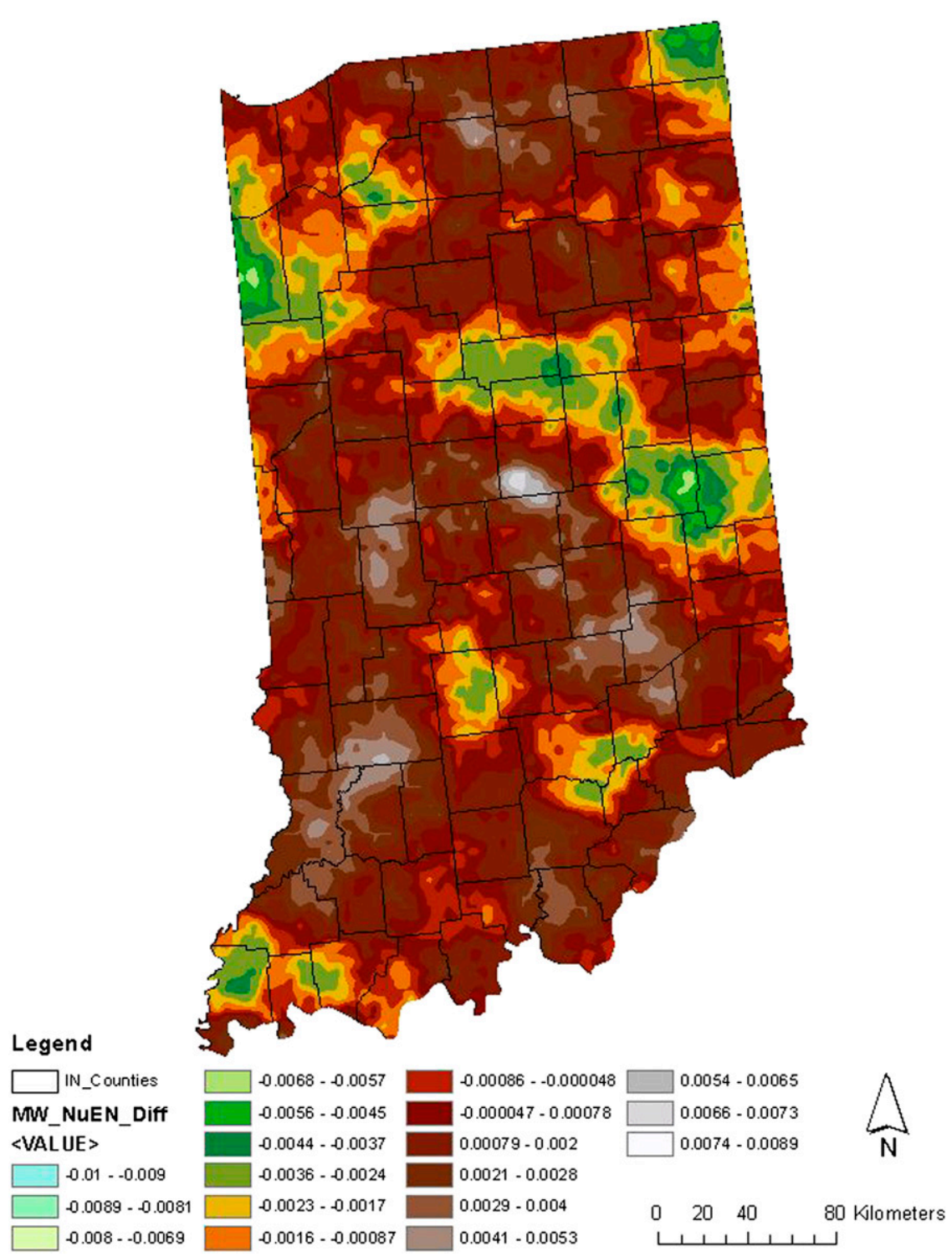

Figure 8. A 1950-2011 F0-F5 tornado touchdown point density map showing the difference between ENSO neutral years tornado touchdown point density and El Niño tornado touchdown point density. Where density values are positive, the ENSO neutral point density value exceeds the El Niño point density value. Where density values are negative, the ENSO neutral point density value is less than the El Niño point density value.

normal; 1-month drought and 1-month normal; and 1-month wet and 1-month normal.

A weak to moderate statistically significant (unpaired $t$ test) correlation of -0.34 is found between 6-month normal rainfall and annual tornado days when classified into drought and normal 6-month cumulative rainfall classes (relationship: normal 


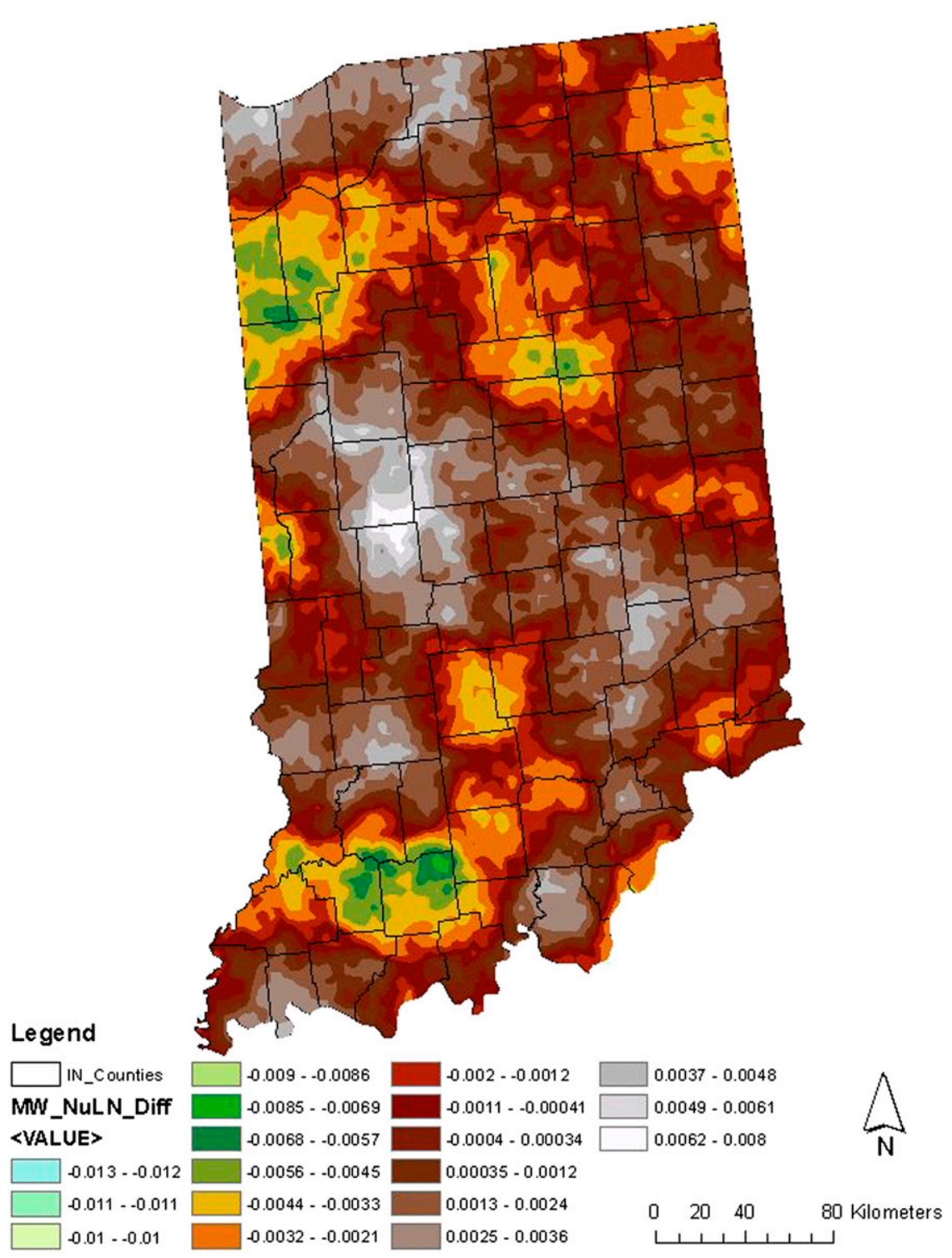

Figure 9. A 1950-2011 F0-F5 tornado touchdown point density map showing the difference between ENSO neutral years tornado touchdown point density and La Niña tornado touchdown point density. Where density values are positive, the ENSO neutral point density value exceeds the La Niña point density value. Where density values are negative, the ENSO neutral point density value is less than the La Niña point density value.

rainfall is equal to average or decreased tornado days). Alternatively, a weak, statistically significant correlation of 0.22 is found between 6-month drought conditions and annual tornado days when classified into drought and normal cumulative rainfall classes (relationship: drought is equal to increased tornado days). A weak, statistically significant correlation of -0.25 is found between 3 -month total normal rainfall and annual tornado days when classified into drought and 
Earth Interactions - Volume 18 (2014) • Paper No. 10 • Page 15

normal cumulative rainfall for the 3-month period (relationship: normal rainfall is equal to average to decreased tornado days). When separating antecedent rainfall totals into wet and normal seasons, a weak to moderate statistically significant correlation of -0.30 is found between the 3 -month cumulative wet conditions (relationship: wetter than normal is equal to decreased tornado days) and annual tornado days, and a weak, statistically significant correlation of 0.23 is found between normal rainfall and annual tornado days when separated into normal and wet classes (relationship: normal is equal to increased tornado days).

These findings look to be opposite of those found by Shepherd et al. (Shepherd et al. 2009) and Andersen and Shepherd (Andersen and Shepherd 2011) for the southeast United States but may be self-consistent. In that, for the southeast, Shepherd et al. (Shepherd et al. 2009) find a decrease in tornado days during spring when drought is present prior to tornado season, suggesting that the dynamic energetics of the region is such that the tornadic potential of storm systems shifts from the southeast and is more prevalent over the Midwest. Results in this study suggest that a 1-, 3-, and 6-month antecedent soil moisture/rainfall feedback hypothesis is sensitive to the length of cumulative rainfall/soil moisture and different hydroclimatic responses stemming from different land use/land cover, different synoptic-scale storm tracks and subsequent mesoscale storm environments, or a combination of both for each location. In general, this analysis shows weak statistically significant correlations that wetter than normal conditions at 3 and 6 months result in decreased average annual tornado days and that drought conditions at 3 and 6 months result in increased average annual tornado days.

\subsection{Spatial analysis}

ArcGIS 10.1 is used to develop the F0-F5 tornado touchdown point density map mentioned in the following discussion of spatial analyses. The tornado touchdown density map is compared to 1) a U.S. Census Bureau 2010 population density (people per square kilometer) raster file; 2) land surface features such as urban centers; 3 ) large changes in elevation (with respect to the overall change of elevation within the study domain); and 4) areas of land surface or land-use heterogeneity.

\subsubsection{Population and tornado touchdown point distribution}

Multiple studies in recent years highlight the population bias on the number of tornadoes reports, with the specific influence of tornado spotting and reporting through increased involvement of storm spotters (McCarthy 2003; McCarthy et al. 2006; Anderson et al. 2007). Past population and tornado report studies agree with a general understanding that the more (fewer) people in a given area, the more (fewer) people that are likely to see and report a tornado (Anderson et al. 2007). Our assessment takes a simple approach to assessing the impacts of Indiana's population distribution on tornado spotting and reporting: the 2010 U.S. Census population density (from SPC SVRGIS) is classified via natural breaks (previously described) into eight classes (class 1: 0-237; class 2: 238-847; class 
Earth Interactions • Volume 18 (2014) • Paper No. 10 • Page 16

Table 4. Percentage of total tornado touchdown points in 1950-2011 that fall within the designated distance in kilometers from the given population density (people per square kilometer based on a national dataset) class. Only those population classes present in Indiana are included in this analysis.

Percentage of total tornadoes in 1950-2012 (1285 total) within 1-4 km of different 2010 population density classes (people per square kilometer)

\begin{tabular}{lccccc}
\hline Class & Class range & $1 \mathrm{~km}$ & $2 \mathrm{~km}$ & $3 \mathrm{~km}$ & $4 \mathrm{~km}$ \\
\hline Class 2 & $238-847$ & 39 & 51 & 60 & 67 \\
Class 3 & $848-1779$ & 24 & 30 & 35 & 41 \\
Class 4 & $1780-3309$ & 10 & 13 & 16 & 19 \\
Class 5 & $3310-6497$ & 1 & 2 & 3 & 4 \\
Class 6 & $6498-13879$ & 0 & 0 & 0 & 1 \\
\hline
\end{tabular}

3: 848-1779; class 4: 1780-3309; class 5: 3310-6497; class 6: 6498-13 879; class 7: 13 880-28 122; and class 8: 28 123-64 482) and converted into shapefiles for buffer analysis. Classes 7 and 8 are not found in Indiana (the SPC SVRGIS population raster file is a national dataset) and are omitted from analysis. Buffer analysis is completed with buffers applied at 1-, 2-, 3-, and 4-km distances from population class to count tornado touchdown points within each search radius. Class 1 of population density is not used, as it captures population density most likely not within/near a population center. Population classes 2-6 are present in Indiana and are used to determine if there is a population bias with documented tornadoes in Indiana. Results show that a large percentage of Indiana tornadoes have in fact touched down in regions of lower population density, with only a few tornadoes touching down within several kilometers of highly populated areas (Table 4). The correlation between the 2010 population density and number of reported tornadoes within $1-4 \mathrm{~km}$ is -0.80 .

Although buffer analysis provides information on proximity of features to other features, an ideal method for this study, buffer analysis results in some biases that contribute to the strong anticorrelation found between population density and tornado touchdown points. Indiana is predominantly a rural state but has a majority of the state's population residing in urban centers. Because of this, Indiana's largest populations reside in a small fraction of the state's total land area. This results in a large decrease in the land area encompassed by the applied buffers, thus decreasing the tornado count by default. The opposite is true for less populated land areas: larger amounts of land area occupied by smaller population density classes results in buffers covering a much larger amount of land area, capturing more tornado touchdown points. Therefore, it is likely that there is a population bias in tornado reporting present in Indiana. Weather professionals in the state of Indiana (and surrounding states) also agree that, in areas of low population density present in hilly and forested regions (e.g., southern Indiana), it is difficult to verify tornado touchdowns (D. McCarthy and J. Gordon, National Weather Service, 2013, personal communication). A similar point has been made with tornado detection in the Great Plains where land is largely agricultural and population is minimal. This scenario provides a decreased probability of visual observation/confirmation of a tornado and results in little to no damage indicators to verify tornado presence (Brooks et al. 2003a; Anderson et al. 2007). 
Earth Interactions • Volume 18 (2014) • Paper No. 10 • Page 17

\subsubsection{Land surface heterogeneity}

Studies have been completed for years showing that boundary layer feedbacks from LULC transition zones differing in latent and sensible heat fluxes can generate or enhance convection provided synoptic conditions are favorable for convection initiation (Clark and Arritt 1995; Pielke 2001; Niyogi et al. 2006; Niyogi et al. 2011; Boyles et al. 2007; Mahmood et al. 2010). Although roughly 50\% of Indiana's tornadoes are QLCS tornadoes (Trapp et al. 2005) whose parent storms develop with strong synoptic forcing, there does appear to be more active regions of tornado touchdown points in Indiana that coincide with LULC. Indiana has two major LULC transition zones close to regions of enhanced tornadic activity: 1) forested hills of southern Indiana (topographic and vegetation variation) to flat farmland on the till plains and 2) larger, relatively urban areas such as Lafayette, Ft. Wayne, Indianapolis, and South Bend surrounded by rural farmland.

A visual, spatial analysis of the possible land surface feedbacks between tornado touchdown locations and different land-use classifications, along with topography, is shown in Figures 10-13. The following two hypotheses are plausible for these regions: 1) Forested hills of southern Indiana to flat farmland on the till plains can generally present atmospheric boundaries of moist static energy and surface roughness. If the synoptic environment is such that storm motion is southwest to the northeast, increased moist static energy (i.e., increased CAPE) from the forest may act to fuel the storm with surface roughness changes, resulting in local vorticity generation. 2) Urban environments result in temperature, moisture, and wind gradients/zones that can serve as sources of vorticity for storm ingestion and development into tornadoes. By default, urban areas result in a population bias to tornado reporting, but numerous accounts of tornadogenesis along local boundaries of moisture, temperature, or wind-shift lines (e.g. Markowski et al. 1998) support the possibility of urban environment contribution to localized increases in tornadogenesis near urban areas.

\subsubsection{Land-use classification buffers}

While currently not explicitly considered as part of the operational forecast process for the probability of tornado development, surface roughness has been analyzed for impacts on vortex dynamics for decades. Dessens (Dessens 1972) conducted a series of simple experiments exploring the effects of surface roughness on an air tornado model using two surface types: a smooth plate to simulate smooth flow and a wood plate with 6-mm pebbles to simulate a rough surface. Dessens's findings show that surface roughness acts to decrease the radius of maximum velocity while increasing the value of maximum vertical velocity (essentially increased stretching of the vortex column). This suggests that surface roughness resulting from features such as trees and houses results in a greater difference between the pressure gradient force and the centrifugal force at the ground boundary layer. This leads to larger convergence in this layer and a subsequent increase of vertical velocities in the vortex core. Dessens's (Dessens 1972) results lend support that land surface features may play a role in tornado touchdown location, as also found in our analysis. Diamond and Wilkins (Diamond and Wilkins 1984) show through laboratory experiments that the translation of tornadoes from different types of land cover (e.g., smooth to rough) 


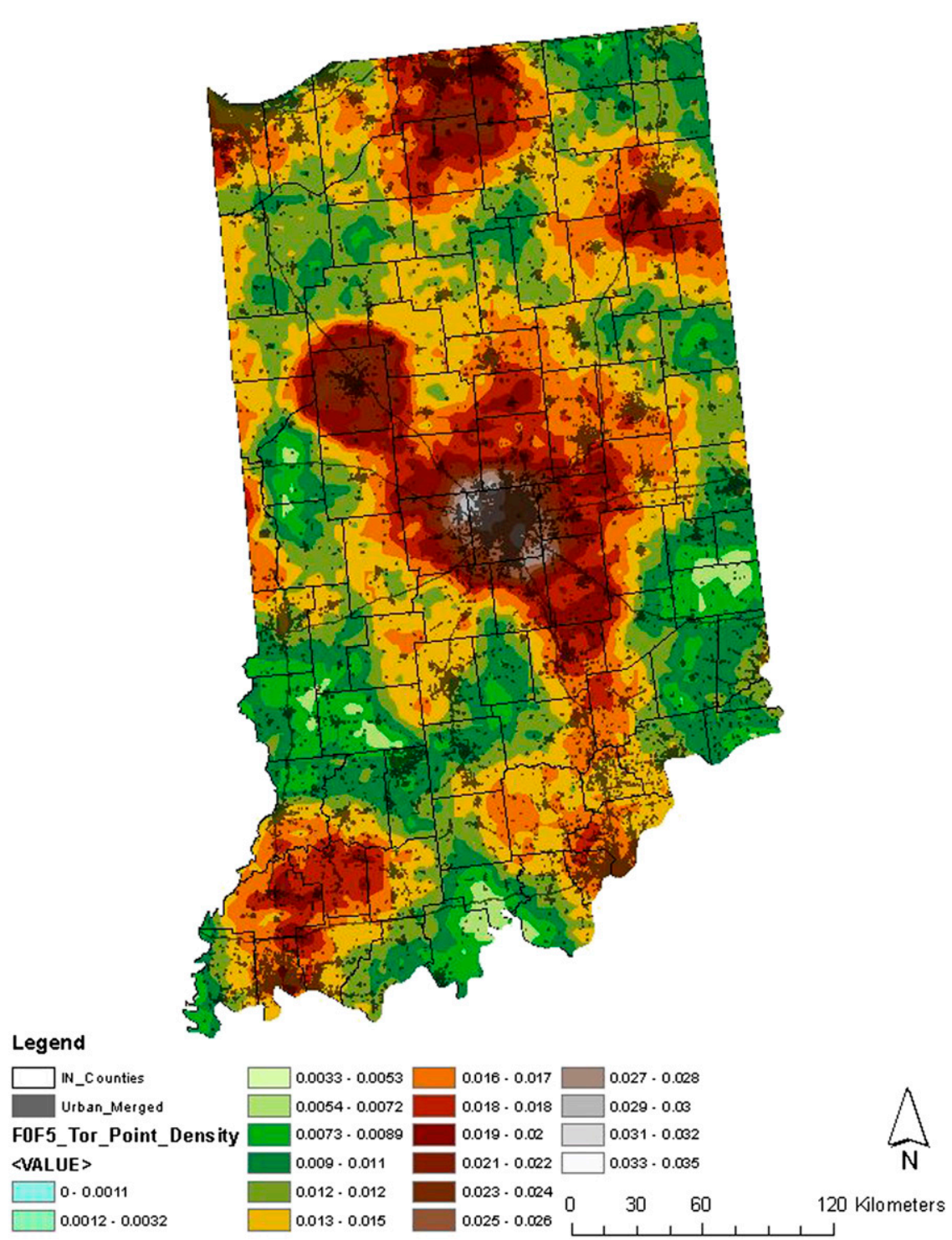

Figure 10. F0-F5 tornado touchdown point density with urban LULC categories as designated by the U.S. Geological Survey (USGS) land-cover classification.

can affect vortex size and structure resulting in the generation of a secondary vortex. These studies suggest important feedbacks occurring between the land surface and tornadoes. However, questions still remain regarding how stormscale dynamics control storm evolution and tornado development and when boundary layer land surface features may contribute to the storm evolution and/or tornado development (Elsom and Meaden 1982; Niyogi et al. 2011).

For the study domain, land-use/land-cover classification is completed using the 2005 enhanced historical land-use and land-cover datasets from the U.S. Geological Survey to assess the possible role of surface roughness associated with 


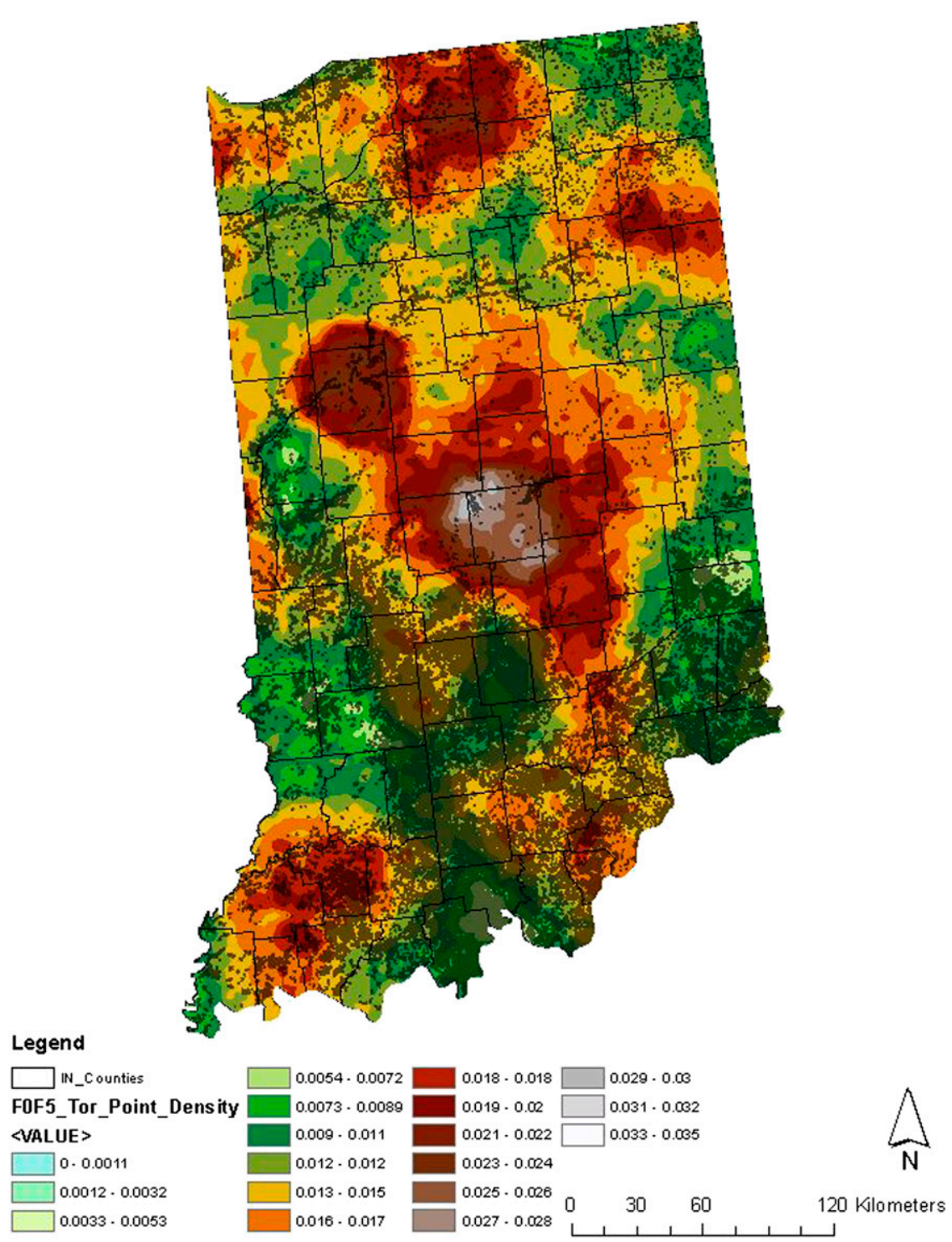

Figure 11. F0-F5 tornado touchdown point density with forest land as designated by the USGS land-cover classification.

different types of LULC on tornadogenesis in Indiana. Polygon shapefiles of LULC data for Indiana are downloaded and separated into forest, urban, agriculture, barren, wetlands/water bodies, and rangeland shapefiles. Rangeland classification (land dominated by grasses and shrubs; Anderson et al. 1976) accounts for little land-cover classification in Indiana and contains no tornado touchdown points and thus is not part of the analysis. The majority of Indiana's land surface is agricultural; thus, it is not used in buffer analysis because of the bias it creates with tornado touchdown points being within a specified distance of agriculture land. Buffer analyses are completed on forest, urban, barren, and wetlands/water body shapefiles at 1 and $2 \mathrm{~km}$ for all tornadoes (F0-F5) and strong tornadoes (F2-F5). 


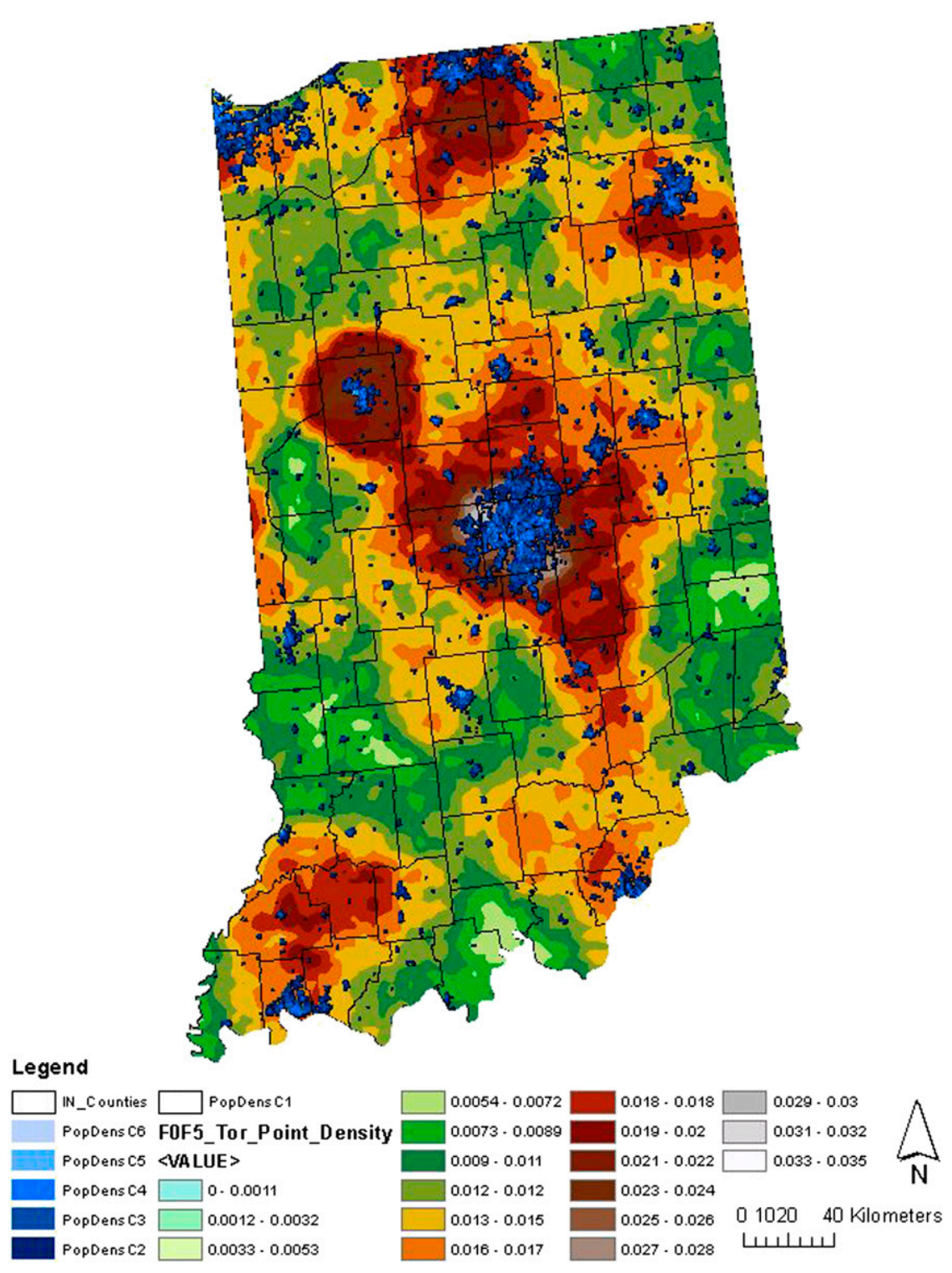

Figure 12. F0-F5 tornado touchdown point density with the 2010 U.S. Census population density of people per square kilometer. While the densest regions (higher count in a given area) of tornado touchdown points in Indiana lie in close proximity to regions of high population, the statistical signal is not significant enough to dismiss land surface feedbacks to the storm environment.

The results from buffers on all tornadoes and strong tornadoes show little variation in the number of tornado touchdown points in relation to land-use category. For all tornadoes, buffer analysis shows $61 \%$ touching down within $1 \mathrm{~km}$ of urban land use, $43 \%$ touching down within $1 \mathrm{~km}$ of forest land use, $12 \%$ touching down within $1 \mathrm{~km}$ of wetland/water body land use, and $8 \%$ touching down within $1 \mathrm{~km}$ of barren land use. The $2-\mathrm{km}$ buffer on all tornadoes results in $78 \%$ touching down 


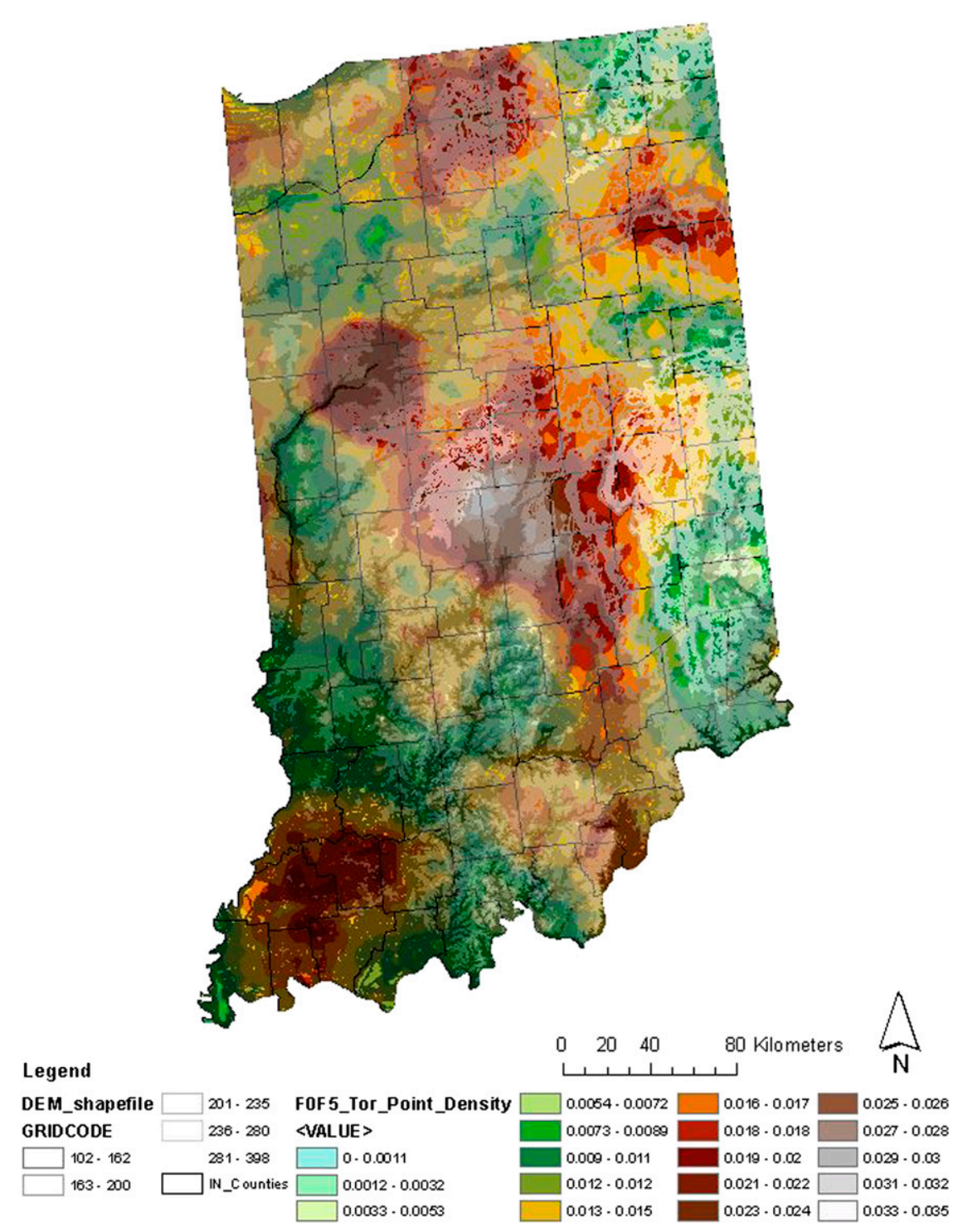

Figure 13. F0-F5 tornado touchdown point density with DEM elevation contours (lines of equal elevation) displayed in gradient color so that lower elevations are dark gray lines and highest elevations are white lines.

within $2 \mathrm{~km}$ of urban land use, $65 \%$ touching down within $2 \mathrm{~km}$ of forest land use, $26 \%$ touching down within $2 \mathrm{~km}$ of wetland/water body land use, and $20 \%$ touching down within $2 \mathrm{~km}$ of barren land use. The decrease in percentage of tornado touchdown points as surface roughness decreases by land-use or landcover type suggests the possible impact of surface roughness on boundary layer structure and tornado feedbacks.

Buffer analysis on strong tornado touchdown points shows similar spatial patterns in relation to land-use and land-cover classifications of urban, forest, wetland/ water body, and barren land use. For strong tornadoes, buffer analysis shows $64 \%$ 
touching down within $1 \mathrm{~km}$ of urban land use (Figure 14), $42 \%$ within $1 \mathrm{~km}$ of forest land use, $11 \%$ within $1 \mathrm{~km}$ of wetland/water body land use, and $7 \%$ within $1 \mathrm{~km}$ of barren land use. The 2-km buffer on strong tornadoes results in $80 \%$ touching down within $2 \mathrm{~km}$ of urban land use, $63 \%$ within $2 \mathrm{~km}$ of forest land use, $25 \%$ within $2 \mathrm{~km}$ of wetland/water body land use, and $21 \%$ within $2 \mathrm{~km}$ of barren land use. Again, the decrease in number of tornado touchdown points appears related to the decrease in surface roughness associated with land-use or land-cover type. While findings from this analysis lend support to increased tornado touchdowns in or near close proximity to land use or land cover associated with increased surface roughness, tornado touchdowns are documented to have impacted all land-use and land-cover types. Thus, although tornadoes in Indiana appear to favor touching down in or near regions of increased surface roughness, no causality can be identified from the analysis, and it is not to say that tornadogenesis should be disregarded over other land-use or land-cover types.

\subsubsection{City centroid and urban area buffers}

A city or town centroid is the geographic center of that city or town. This differs from the land-use categorization of urban area or land cover, as the land-use categorization is an area of land and the city centroid is a point. Incremental 1-km circular buffers at $1,2,3, \ldots$, and $20 \mathrm{~km}$ are applied around an "IN_Cities" point shapefile, which is inclusive of 70 cities, towns, census designated places, and consolidated cities in Indiana (Figure 15). A count of the number of tornado touchdown points within each search radius is determined and converted to a percentage of total tornadoes (1285 in all in the dataset for 1950-2011) within that distance. A regression analysis (Figure 16) is completed between the percentage of tornado touchdown points lying within the search radius and the distance of the search radius, revealing a linear trend in the number of observed tornado touchdown points with increasing distance from the city or town center. These findings are similar to those discussed in Elsom and Meaden (Elsom and Meaden 1982). The change in percentage of tornado touchdown points between 1-km buffer intervals experiences an increase of one standard deviation above the mean percentage change $\left(2.8 \% \mathrm{~km}^{-1}\right)$ at the $2-, 14-$, and $15-\mathrm{km}$ range from the centroid location. To identify any possible relationship between urban land areas in square kilometers, the same buffer analysis process is completed on an urban area shapefile for $1-10-\mathrm{km}$ distances. When analyzing the number of tornado touchdown points in relation to a distance from urban land areas $20 \mathrm{~km}^{2}$ in area and greater, a linear trend is also found. When looking at the change in percentage of tornado touchdown points between 1-km intervals there are again two buffers that show an increase of one standard deviation above the mean percentage change $\left(1.9 \% \mathrm{~km}^{-1}\right)$ at the 3 - and $8-\mathrm{km}$ range from the edge of the urban area. These "rings" of slightly increased tornado touchdown points are similar to the suggested "tornado belt" coined by Fujita (Fujita 1973) after Fujita's review of 14 tornadoes around Tokyo from 1962 to 1971 (Elsom and Meaden 1982). The noted increase in percentage of tornado touchdown points at 2,14 , and $15 \mathrm{~km}$ for city centroids and 3 and $8 \mathrm{~km}$ for urban areas greater than $20 \mathrm{~km}^{2}$ suggest the possibility of preferential occurrence of tornadoes with respect to urban boundaries that develop near these locations. 


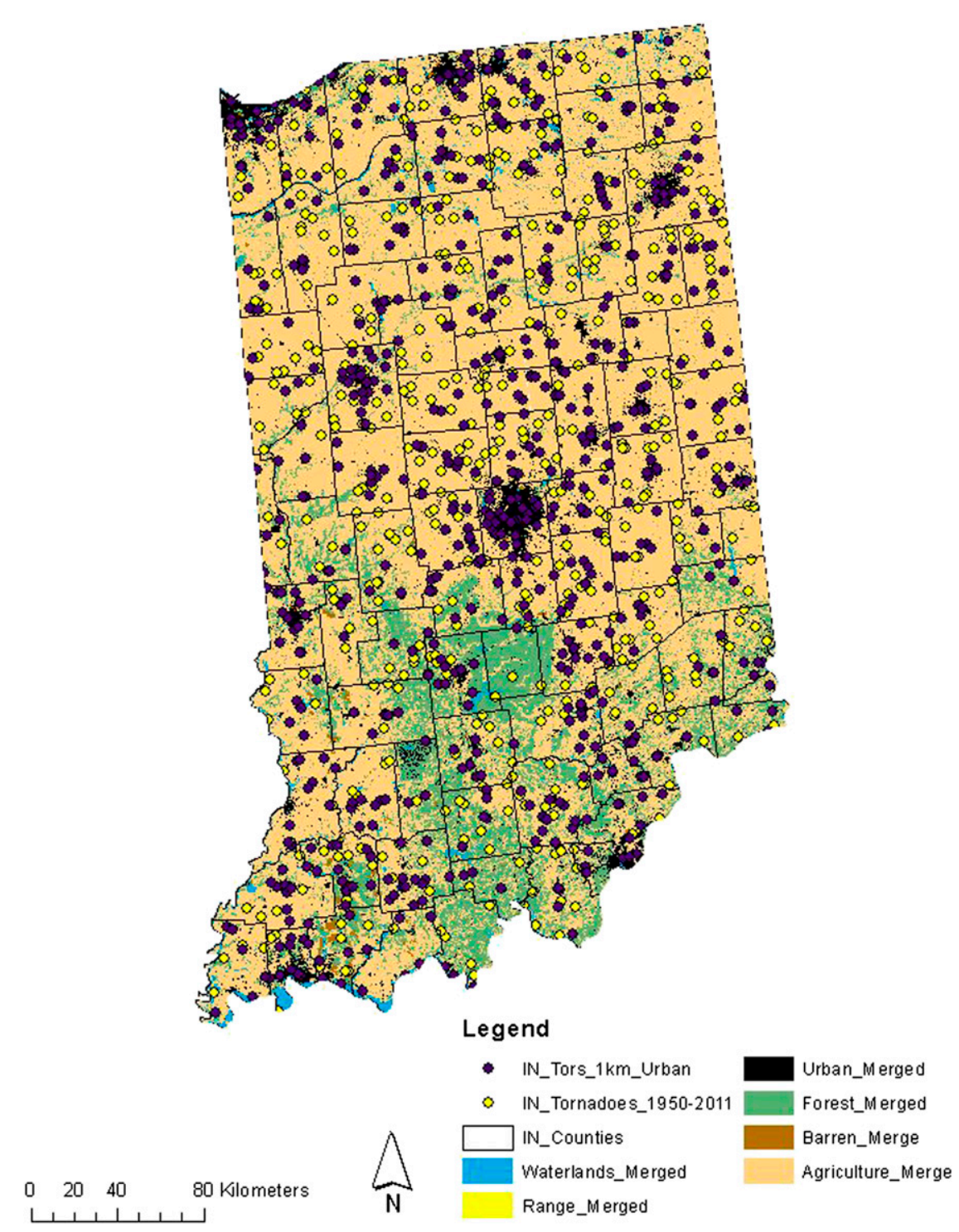

Figure 14. Map of Indiana showing USGS land-cover classifications of wetlands/ water bodies, range land, urban areas, barren land, and agriculture. Tornado touchdown points within $1 \mathrm{~km}$ of an urban land-use classification are in purple. Yellow points represent those tornado touchdown points not within $1 \mathrm{~km}$ of an urban land-cover classification.

\subsubsection{Elevation/topography}

Coleman (Coleman 2010) and Bosart et al. (Bosart et al. 2004) discuss the possible role of topography on the generation of increased local vorticity, contributing favorable to tornadogenesis with an emphasis on river valleys and mountains/hills and associated valleys. To investigate the possibility of this occurring in Indiana, a digital elevation model (DEM) in raster format is downloaded and used to develop a digital elevation model shapefile. The slope tool in 


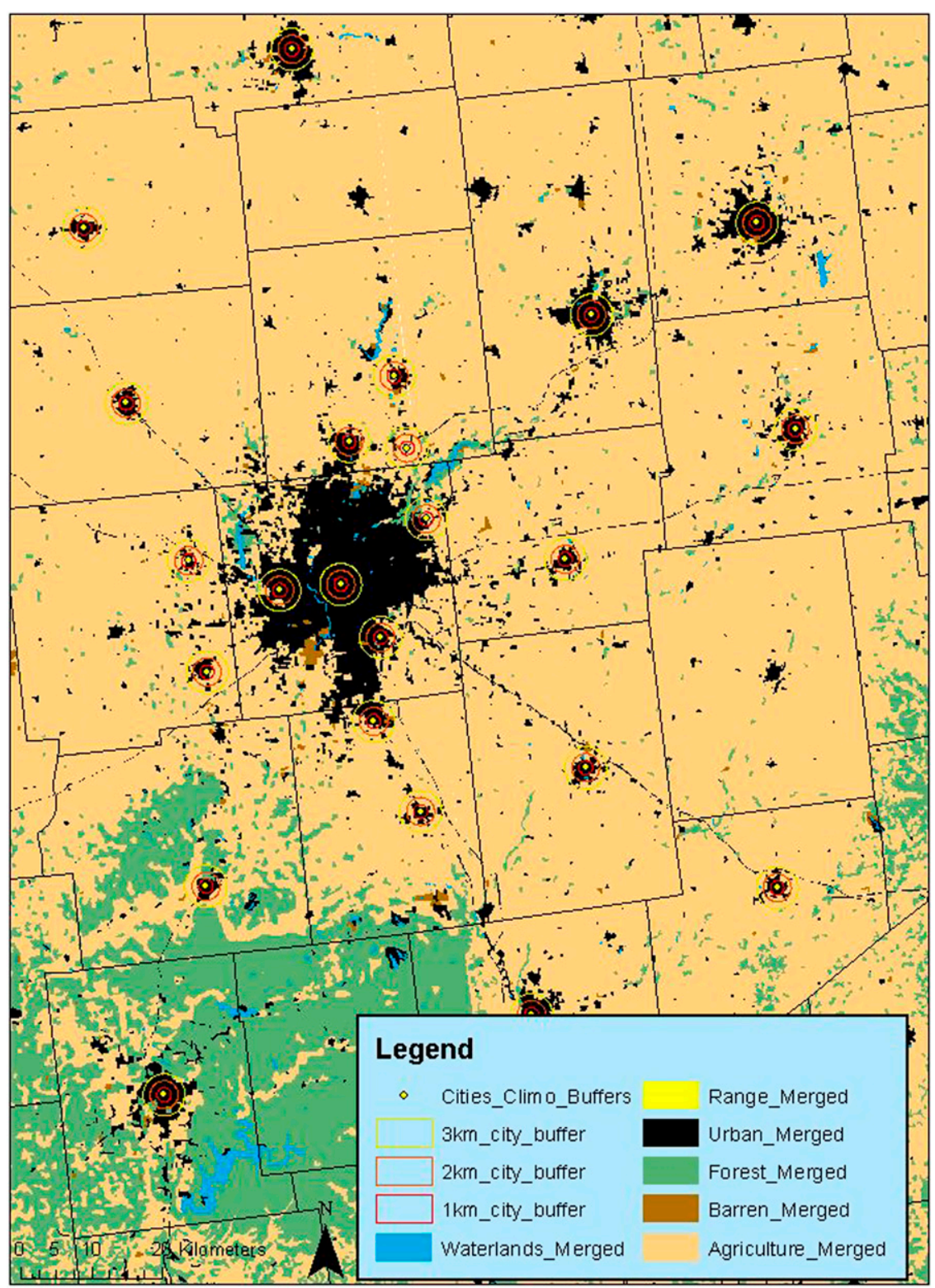

Figure 15. Zoomed-in map of land-use classifications; city centroids (yellow points); and 1-, 2-, and 3-km buffers. Tornado touchdown points are in purple. This image corresponds to Indianapolis, the largest area of urban to rural heterogeneity in Indiana.

ArcGIS is used to compute changes in slope (in degrees) to assess if changes in elevation have any impact on tornado development within close proximity to sharp changes in elevation. Surface slope changes are categorized as 1) change in slope of $5^{\circ}$ or more or 2) change in slope of less than $5^{\circ}$ between each grid cell of the raster surface. The $5^{\circ}$ change in slope over one DEM grid cell is selected because it represents an elevation change of roughly one-half of the total 
Earth Interactions - Volume 18 (2014) - Paper No. 10 • Page 25

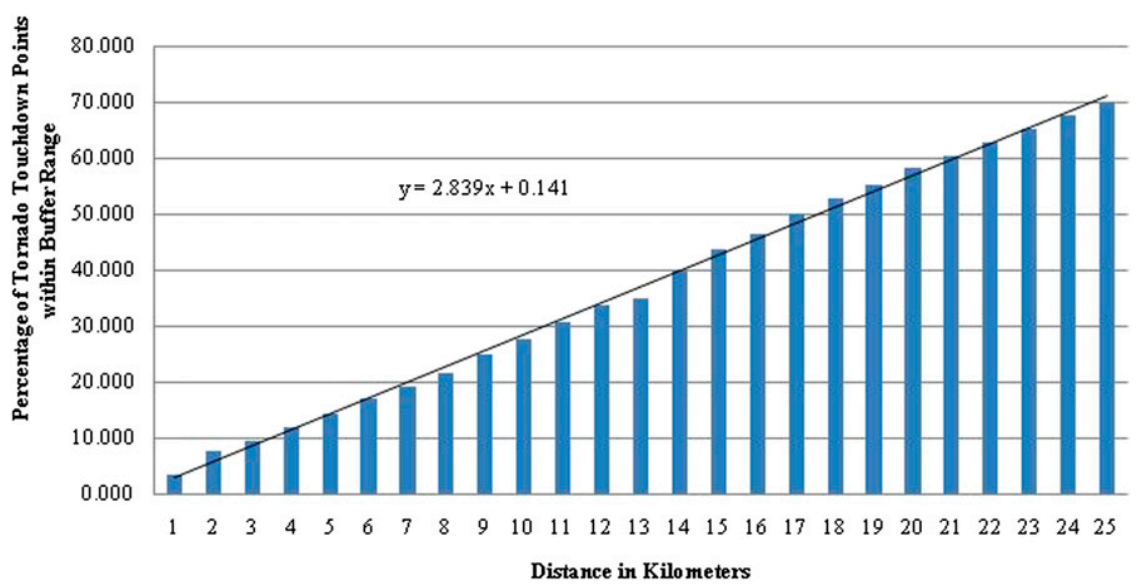

Figure 16. Regression plot of city centriod buffer distance and the percentage of F0F5 tornadoes occurring within the specified distance. A near-geometric relationship exists between the two, showing that a small amount of tornado touchdown points are close to city centers and increase in number with distance from the city.

elevation change between Indiana's highest and lowest points (383 and $98 \mathrm{~m}$, respectively). The raster surface is comprised of cells $94 \mathrm{~m}$ by $94 \mathrm{~m}$; thus, the change in slope is computed over a distance of $94 \mathrm{~m}$.

All tornadoes are once again reviewed in relation to elevation changes. Of all tornado touchdown points, $180(14 \%)$ are located within $1 \mathrm{~km}$ of surface slope changing by $5^{\circ}$ or more. Increasing the search distance to $2 \mathrm{~km}$ increases the amount of tornado touchdown points to $271(21 \%)$. Strong tornadoes result in the same values: 53 of 380 (14\%) strong tornadoes have touched down within $1 \mathrm{~km}$ of surface slope changing by $5^{\circ}$ or more and 81 of $380(21 \%)$ strong tornadoes have touched down within $2 \mathrm{~km}$ of surface slope changing by $5^{\circ}$ or more. Changing the search radius to determine the number of tornadoes touching down within $1 \mathrm{~km}$ of surface slope changes of less than $5^{\circ}$ results in 1281 of 1285 tornado touchdown points (F0-F5) being selected. For strong tornadoes, all 380 tornado touchdown points are selected. Changes in topography over short distances do not appear to have as strong as a relationship to the spatial location of tornado touchdowns in the relatively flat landscape across Indiana as compared to land-use type. However, the increased number tornado touchdown points east of the Knobstone Escarpment (a steep slope or cliff that results from erosion or faulting processes and separates two relatively level or more gently sloping areas of terrain) where the Scottsburg Lowlands rise into the Muscatatuck Plateau and Dearborn Uplands (Figure 17) suggest possible terrain feedbacks such as those mentioned by Coleman (Coleman 2010) and Bosart et al. (Bosart et al. 2004).

\section{Conclusions}

Tornado day analysis for all, weak, and strong tornadoes in 1950-2012 shows a distinct spring tornado season in Indiana with a majority of tornado days more 


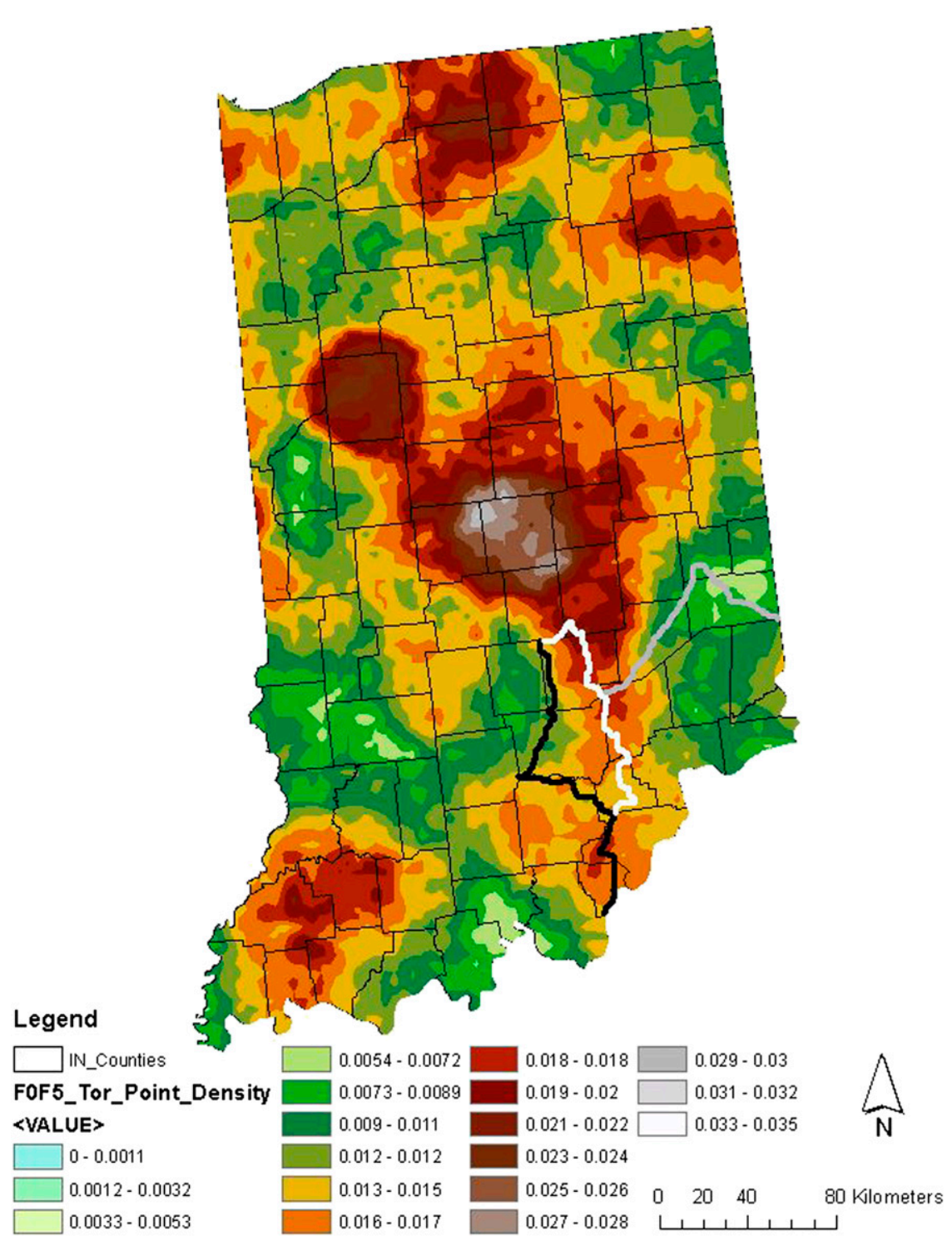

Figure 17. F0-F5 tornado touchdown point density map with region of increased tornado touchdown points (circled in yellow) east of the Knobstone Escarpment (thick black line) where the Scottsburg Lowlands (east of black line and west of white line) rise to the Muscatatuck Plateau and Dearborn Uplands (east of white line and south of gray line).

conducive to weak tornadoes. In Indiana, tornado days occur most frequently during the months of June, May, and July (descending order). These three months are also the defining season for weak tornado days. A slight shift in tornado day occurrence for strong tornadoes is seen with the greatest number of strong tornado days occurring during the months of April (37 days), June (37 days), and May (30 days) for the 1950-2012 period. These findings are comparative to the 
average tornado frequency by month (1991-2010) as May, June, and April (in descending order) (National Climatic Data Center 2013). Total tornado days per year have not increased through time and, when reviewed at 30-yr climatological intervals, show a slight insignificant decrease in the average number of tornado days per year for all, weak, and strong tornadoes in Indiana similar to findings at the national level as discussed by McCarthy and Schaefer (McCarthy and Schaefer 2004). Thus, no trend or conclusions regarding tornado days per year for 1950-2012 can be made from this analysis, agreeing with findings presented in Kunkel et al. (Kunkel et al. 2013). From 1950 to 2012, the years that are most active in Indiana (total tornado days per year that are one standard deviation or greater) span the entire time frame of this study (1950-2012). However, reviewing tornado day data in terms of just strong tornadoes, there has not been an active year in Indiana since 1980. All other active years are 1968 or earlier, the time frame of historic tornado records that some studies suggest show a bias toward overclassification of tornado intensity because of the procedures used to assign F-scale ranking prior to the development of the F scale (McCarthy 2003; McCarthy et al. 2006; Edwards et al. 2013). The most active time of day for weak tornadoes in local standard time (LST) is 1600-1900 LST; strong tornadoes have two active times, 1400-1600 LST and 1700-2000 LST; and all tornadoes are most active at 1600-2000 LST.

The spatial analysis of this climatology (touchdown distribution across the state) agrees with the findings of Ashley (Ashley 2007), Concannon et al. (Concannon et al. 2000), and Dixon et al. (Dixon et al. 2011). There are pronounced areas throughout central Indiana that show locales of enhanced tornado occurrences. The spatial location of increased tornado touchdown points in the northern portion of the state can be largely attributed to outbreak events, whereas the central Indiana axis of enhanced tornado activity is influenced by a larger variety of tornado events.

ENSO phases are not found to be related to the number of tornado days but do appear to impact the spatial distribution of tornado events across the state. The map of El Niño tornado touchdowns show that tornado touchdown points are more widespread but concentrated across central Indiana. The neutral phase map shows a pronounced region of tornado touchdown points that coincides with the overall F0F5 tornado touchdown point distribution. The La Niña maps show that tornado touchdown points appear to be centrally located around Indianapolis and in a cluster in southwest Indiana but are more widespread across northern Indiana. A predominant ENSO phase does not appear to favor more or fewer tornado days in a given year across Indiana; however, the rate and intensity at which ENSO phase changes occur may impact the tornado season (Lee et al. 2013). Antecedent cumulative rainfall amounts 6 and 3 months prior to a given year's tornado season when separated into normal and drought conditions, along with 3 months prior when separated into normal and wet conditions appear to have a slight trend toward fewer annual tornado days for the following season/year.

Antecedent rainfall analysis of drought and normal conditions and then wetter than normal and normal conditions at 1,3, and 6 months is completed for the study domain to identify possible soil moisture memory feedbacks to the convective storm environment. This analysis shows weak, statistically significant correlations that wetter than normal conditions at 3 and 6 months result in decreased average 
Earth Interactions - Volume 18 (2014) - Paper No. 10 - Page 28

annual tornado days and that drought conditions at 3 and 6 months result in increased average annual tornado days.

Population distribution appears to play a role in the recorded number of tornadoes in Indiana, with the largest density of tornado touchdown points near the most densely populated county in the state. However, population bias may not be the sole contributing factor to the spatial distribution of tornado reports. Buffer analysis completed with city centroids and urban land areas shows a large percentage of total tornadoes touching down in low population density areas. This is likely a result of buffer analysis and population density clustering, as explained in section 3.2.1. Until tornado touchdown verification processes in some parts of the study domain are improved, the consensus of tornado touchdown locations having a population bias cannot be confidently made.

Land surface heterogeneity and associated surface roughness of land surface type appear to have a relationship with tornado touchdown locations in the study domain. Buffer analysis on land-use types show that for all tornadoes $61 \%$ have touched down within $1 \mathrm{~km}$ of urban land use and $43 \%$ have touched down within $1 \mathrm{~km}$ of forest land use. A total of $64 \%$ and $42 \%$ of strong tornadoes have touched down in urban and forest land-use types, respectively. The percentage of tornadoes touching down within $1 \mathrm{~km}$ of land use with decreased surface roughness (water bodies and barren land use) is found to be much lower. Changes in topography over short distances do not appear to have as strong as a relationship to the spatial location of tornado touchdowns in the relatively flat landscape across Indiana as compared to land-use type.

Recent assessment of urban thunderstorms over the Indianapolis region (Niyogi et al. 2011) shows a possible relationship between urban landscapes and thunderstorm structure and life cycles. Pryor and Kurzhal (Pryor and Kurzhal 1997) suggest a trend of tornado touchdown points from 1950 to 1995 being located in counties with high surface roughness values and decreased population densities. The concentric rings/buffers at $1-\mathrm{km}$ intervals of tornado touchdown points from cities and towns in Indiana show similar distributions as those discussed in Elsom and Meaden (Elsom and Meaden 1982) in greater London for weak tornadoes and in Fujita (Fujita 1973) for tornadoes around Tokyo. Topographic and elevation influences visually appear to play a possible role in Indiana tornado touchdown locations as well: most specifically, east of the Knobstone Escarpment, where terrain-induced surface vorticity as described by Coleman (Coleman 2010) and Bosart et al. (Bosart et al. 2004) could be generated provided surface wind conditions or other features of the storm environment act favorably in this area.

The comprehensive tornado climatology presented herein investigates and assesses the possible role that different climatological features such as ENSO, antecedent rainfall conditions, population density, land use/land cover, and topography have on tornado climatology in Indiana. It is apparent that there are local as well as climate variability feedbacks to the 1950-2010 tornado climatology. Changes in surface roughness and surface energy budgets associated with land surface heterogeneity appear to play a possible role in tornado touchdown locations because of the generation of local vorticity boundaries. Identification of land-use transition zones in convectively unstable environments while forecasters try to identify tornadogenesis may be worth considering as part of the forecast process in the future upon further analysis of land surface heterogeneity and tornado 
Earth Interactions - Volume 18 (2014) • Paper No. 10 • Page 29

climatology. The GIS framework used in this study presents some limitations and uncertainties in the spatial climatology, especially with buffer analysis. Despite the visible population bias present in figures, tornado verification in regions of the study domain remain a challenge, lending support to the premise that land surface heterogeneity may impact tornado climatology in Indiana.

Acknowledgments. We thank Evan Bentley, Northern Indiana National Weather Service, for help in assembling the tornado day climatology data and Dr. Ernest Agee, Purdue University, for review of portions of this manuscript. Research benefited in part by NASA Fellowship Grant 104798 awarded to O. Kellner, NSF STRONG Cities Project: NSF CBET 1250232, and Development of a High-resolution Drought Trigger Tool (HIRDTT) for the United States, Agriculture and Food Research Initiative Competitive Grant 201167019-20042.

\section{References}

Agee, E. M., 1970: The climatology of Indiana tornadoes. Proc. Indiana Acad. Sci., 79, 299-308.

— Niña. Proc. 19th Conf. on Severe Local Storms, Minneapolis, MN, Amer. Meteor. Soc., 287290.

— cation of tornado events. Wea. Forecasting, 24, 609-617, doi:10.1175/2008WAF2222163.1.

Andersen, T. K., and J. M. Shepherd, 2011: Seasonal predictability of tornadic activity using antecedent soil moisture conditions. Earthzine. [Available online at http://www.earthzine.org/ 2011/06/10/seasonal-predictability-of-tornadic-activity-using-antecedent-soil-moistureconditions/.]

Anderson, C. J., C. K. Wikle, Q. Zhou, and J. A. Royle, 2007: Population influence on tornado reports in the United States. Wea. Forecasting, 22, 571-579, doi:10.1175/WAF997.1.

Anderson, J. R., E. E. Hardy, J. T. Roach, and R. E. Witmer, 1976: A land use and land cover classification system for use with remote sensor data. United States Geological Survey Rep., $41 \mathrm{pp}$.

Arguez, A. A., and R. S. Vose, 2011: The definition of the standard WMO climate normal. Bull. Amer. Meteor. Soc., 92, 699-704, doi:10.1175/2010BAMS2955.1.

Ashley, W. S., 2007: Spatial and temporal analysis of tornado fatalities in the United States: 18802005. Wea. Forecasting, 22, 1214-1228, doi:10.1175/2007WAF2007004.1.

Bornstein, R., and Q. Lin, 2000: Urban heat islands and summertime convective thunderstoms in Atlanta: Three case studies. Atmos. Environ., 34, 507-516, doi:10.1016/ S1352-2310(99)00374-X.

Bosart, L. F., K. LaPenta, A. Seimon, M. Dickinson, and T. J. Galarneau Jr., 2004, Terrain-influenced tornadogenesis in the northeastern United States. Preprints, 11th Conf. on Mountain Meteorology and the Annual Mesoscale Alpine Program (MAP), Bartlett, NH, Amer. Meteor. Soc., P17.3. [Available online at https://ams.confex.com/ams/pdfpapers/77126.pdf.]

Boyles, R., S. Raman, and A. Sims, 2007: Sensitivity of mesoscale precipitation dynamics to surface soil and vegetation contrasts over the Carolina Sandhills. Pure Appl. Geophys., 164, 1547-1576, doi:10.1007/s00024-007-0227-2.

Bozeman, M. L., D. Niyogi, S. Gopalakrishnan, F. D. Marks Jr., X. Zhang, and V. Tallapragada, 2012: An HWRF-based ensemble assessment of the land surface feedback on the postlandfall intensification of Tropical Storm Fay (2008). Nat. Hazards, 63, 1543-1571, doi:10.1007/s11069-011-9841-5. 
Earth Interactions - Volume 18 (2014) • Paper No. 10 • Page 30

Brooks, H. E., C. A. Doswell III, and M. P. Kay, 2003a: Climatological estimates of local daily tornado probability for the United States. Wea. Forecasting, 18, 626-640, doi:10.1175/ 1520-0434(2003)018<0626:CEOLDT $>2.0$. CO;2.

— J. W. Lee, and J. P. Craven, 2003b: The spatial distribution of severe thunderstorm and tornado environments from global reanalysis data. Atmos. Res., 67-68, 73-94, doi:10.1016/ S0169-8095(03)00045-0.

Brotzge, J., S. Erickson, and H. Brooks, 2011: A 5-yr climatology of tornado false alarms. Wea. Forecasting, 26, 534-544, doi:10.1175/WAF-D-10-05004.1.

Changnon, S. A., 1982: Trends in tornado frequencies. Proc. 12th Conf. on Severe Local Storms, San Antonio, TX, Amer. Meteor. Soc., 42-44.

— , and P. T. Schickedanz, 1969: Utilization of hail-day data in designing and evaluating hail suppression projects. Mon. Wea. Rev., 97, 95-102, doi:10.1175/1520-0493(1969)097<0095: UOHDID $>2.3 . \mathrm{CO} ; 2$.

Cheresnick, D. R., and J. B. Basara, 2005: The impact of land-atmosphere interactions on the Benson, MN tornado of 11 June 2011. Bull. Amer. Meteor. Soc., 86, 637-642, doi:10.1175/BAMS-86-5-637.

Clark, C., and R. Arritt, 1995: Numerical simulations of the effect of soil moisture and vegetation cover on the development of deep convection. J. Appl. Meteor., 34, 2029-2045, doi:10.1175/ 1520-0450(1995)034<2029:NSOTEO > 2.0.CO;2.

Coleman, T. A., 2010: The effects of topography and friction on mesocyclones and tornadoes. Preprints, 25th Conf. on Severe Local Storms, Denver, CO, Amer. Meteor. Soc., P8.12.

Concannon, P. R., H. E. Brooks, and C. A. Doswell III, 2000: Climatological risk of strong and violent tornadoes in the United States. Preprints, Second Symp. Environmental Applications, Long Beach, CA, Amer. Meteor. Soc., 9.4.

Cook, A. R., and J. T. Schaefer 2008: The relation of El Niño-Southern Oscillation (ENSO) to winter tornado outbreaks. Mon. Wea. Rev., 136, 3121-3137, doi:10.1175/2007MWR2171.1.

de Smith, M., P. Longley, and M. Goodchild, cited 2013: Geospatial analysis: A comprehensive guide. [Available online at http://www.spatialanalysisonline.com/HTML/index.html.]

Dessens, J., Jr., 1972: Influence of ground roughness on tornadoes: A laboratory simulation. J. Appl. Meteor, 11, 72-75, doi:10.1175/1520-0450(1972)011<0072:IOGROT>2.0.CO;2.

Diamond, C. J., and E. M. Wilkins, 1984: Translation effects on simulation tornadoes. J. Atmos. Sci., 41, 2574-2580, doi:10.1175/1520-0469(1984)041<2574:TEOST>2.0.CO;2.

Dixon, P. G., A. E. Mercer, J. Choi, and J. S. Allen, 2011: Tornado risk analysis: Is Dixie Alley an extension of Tornado Alley? Bull. Amer. Meteor. Soc., 92, 433-441, doi:10.1175/ 2010BAMS3102.1.

Doswell, C. A., III, 2007: Small sample size and data quality issues illustrated using tornado occurrence data. Electron. J. Severe Storms Meteor., 2 (5), 1-16.

Edwards, R., cited 2011: Frequently asked questions about tornadoes. Storm Prediction Center. [Available online at http://www.spc.noaa.gov/faq/tornado/\#About.]

— J. J. LaDue, J. T. Ferree, K. Scharfenberg, C. Maier, and W. L. Coulbourne, 2013: Tornado intensity estimation. Bull. Amer. Meteor. Soc., 94, 641-653, doi:10.1175/BAMS-D-11-00006.1.

Elsom, D. M., and G. T. Meaden, 1982: Suppression and dissipation of weak tornadoes in metropolitan areas: A case study of greater London. Mon. Wea. Rev., 110, 745-756, doi:10.1175/ 1520-0493(1982) $110<0745:$ SADOWT $>2.0 . C O ; 2$.

Fujita, T. T., 1973: Tornadoes around the world. Weatherwise, 26, 56-83, doi:10.1080/ 00431672.1973 .9931633$.

Holt, T., D. Niyogi, F. Chen, M. A. LeMone, K. Manning, and A. L. Qureshi, 2006: Effect of landatmosphere interactions on the IHOP 24-25 May 2002 convection case. Mon. Wea. Rev., 134, 113-133, doi:10.1175/MWR3057.1.

Kellner O., D. Niyogi, M. Lei, A. Kumar 2012: The role of anomalous soil moisture on the inland reintensification of Tropical Storm Erin (2007). Nat. Hazards, 63, 1575-1600, doi:10.1007/ s11069-011-9966-6. 


\section{Earth Interactions - Volume 18 (2014) - Paper No. 10 • Page 31}

Kis, A. K., and J. M. Straka, 2010: Nocturnal tornado climatology. Wea. Forecasting, 25, 545-561, doi:10.1175/2009WAF2222294.1.

Kunkel, K., and Coauthors, 2013: Monitoring and understanding trends in extreme storms. Bull. Amer. Meteor. Soc., 94, 499-514, doi:10.1175/BAMS-D-11-00262.1.

Lee, S. K., R. Atlas, D. Enfield, C. Wang, and L. Hailong, 2013: Is there an optimal ENSO pattern that enhances large-scale atmospheric processes conducive to tornado outbreaks in the United States? J. Climate, 26, 1626-1642, doi:10.1175/JCLI-D-12-00128.1.

Mahmood, R., and Coauthors, 2010: Impacts of land use/land cover change on climate and future research priorities. Bull. Amer. Meteor. Soc., 91, 37-46, doi:10.1175/2009BAMS2769.1.

— - A. Littell, K. G. Hubbard, and J. You, 2012: Observed data-based assessment of relationships among soil moisture at various depths, precipitation, and temperature. Appl. Geogr., 34, 255264, doi:10.1016/j.apgeog.2011.11.009.

Markowski, P. M., E. N. Rasmussen, and J. M. Straka, 1998: The occurrence of tornadoes in supercells interacting with boundaries during VORTEX-95. Wea. Forecasting, 13, 852-859, doi:10.1175/1520-0434(1998)013<0852:TOOTIS >2.0.CO;2.

Mayes, B. E., C. Cogil, G. R. Lussky, J. S. Boyne, and R. Ryrholm, 2007: Tornado and severe weather climatology and predictability by ENSO phase in the north central U.S.: A compositing study. Preprints, 19th Conf. on Climate Variability and Change, San Antonio, TX, Amer. Meteor. Soc., JP4.17. [Available online at https://ams.confex.com/ams/pdfpapers/ 117083.pdf.]

McCarthy, D. W., 2003: NWS tornado surveys and the impact on the National Tornado Database. Preprints, First Symp. F-Scale and Severe-Weather Damage Assessment, Long Beach, CA, Amer. Meteor. Soc., 3.2. [Available online at https://ams.confex.com/ams/pdfpapers/55718. pdf.]

— and J. Schaefer, 2004: Tornado trends over the past thirty years. Preprints, 14th Conf. Applied Climatology, Seattle, WA, Amer. Meteor. Soc., 3.4. [Available online at https://ams.confex. com/ams/pdfpapers/72089.pdf.]

_, _ , and R. Edwards, 2006: What are we doing with (or to) the F-Scale? Preprints, 23rd Conf. Severe Local Storms, St. Louis, MO, Amer. Meteor. Soc., 5.6. [Available online at https://ams.confex.com/ams/pdfpapers/115260.pdf.]

National Climatic Data Center, cited 2013: U.S. tornado climatology. [Available online at http:// www.ncdc.noaa.gov/oa/climate/severeweather/tornadoes.html.]

Niyogi, D., T. Holt, S. Zhong, P. C. Pyle, and J. Basara, 2006: Urban and land surface effects on the 30 July 2003 mesoscale convective system event observed in the southern Great Plains. J. Geophys. Res., 111, D19107, doi:10.1029/2005JD006746.

—, P. Pyle, M. Lei, S. Pal Arya, C. M. Kishtawal, M. Shepherd, F. Chen, and B. Wolfe, 2011: Urban modification of thunderstorms: An observational storm climatology and model case study for the Indianapolis urban region. J. Appl. Meteor. Climatol., 50, 1129-1144, doi:10.1175/2010JAMC1836.1.

Nunn, K. H., and A. T. DeGaetano, 2004: The El Niño-Southern Oscillation and its role in coldseason tornado outbreak climatology. Preprints, 14th Conf. on Applied Climatology, Seattle, WA, Amer. Meteor. Soc., JP5.2. [Available online at https://ams.confex.com/ams/pdfpapers/ 71587.pdf.]

Pielke, R. A., Sr., 2001: Influence of the spatial distribution of vegetation and soils on the prediction of cumulus convective rainfall. Rev. Geophys., 39, 151-177, doi:10.1029/1999RG000072.

— - and Coauthors, 2011: Land use/land cover changes and climate: Modeling analysis and observational evidence. Wiley Interdiscip. Rev.: Climate Change, 2, doi:10.1002/wcc.144.

Pryor, S. C., and T. Kurzhal, 1997: A tornado climatology for Indiana. Phys. Geog., 18, 525-543.

Rauber, R. M., J. E. Walsh, and D. J. Charlevoix, 2005: Severe and Hazardous Weather: An Introduction to High Impact Meteorology. 2nd ed. Kendall Hunt, 558 pp. 
Earth Interactions - Volume 18 (2014) • Paper No. 10 • Page 32

Rhome, J. R., D. Niyogi, and S. Raman, 2000: Mesoclimatic analysis of severe weather and ENSO interactions in North Carolina. Geophys. Res. Lett., 27, 2269-2272, doi:10.1029/ 1999GL011327.

Rose, S. F., P. V. Hobbs, J. D. Locatelli, and M. T. Stoelinga, 2004: A 10-yr climatology relating the locations of reported tornadoes to the quadrants of upper-level jet streaks. Wea. Forecasting, 19, 301-309, doi:10.1175/1520-0434(2004)019<0301:AYCRTL >2.0.CO;2.

Ross, T., N. Lott, A. Graumann, and S. McCown, cited 2011: Climate-Watch, April 2001. National Oceanic and Atmospheric Administration/National Climatic Data Center. [Available online at http://www.ncdc.noaa.gov/oa/climate/extremes/2001/april/extremes0401.html.]

Schneider, R., J. D. Schaefer, and H. E. Brooks, 2004: Tornado outbreak days: An updated and expanded climatology (1875-2003). Preprints, 22nd Conf. on Severe Local Storms, Hyannis, MA, Amer. Meteor. Soc., P5.1. [Available online at https://ams.confex.com/ams/pdfpapers/ 82031.pdf.]

Shepherd, M., D. Niyogi, and T. Mote, 2009: A seasonal-scale climatological analysis correlating spring tornadic activity with antecedent fall-winter drought in the southeastern United States. Environ. Res. Lett., 4, 024012, doi:10.1088/1748-9326/4/2/024012.

Smith, B. T., R. L. Thompson, J. S. Grams, C. Broyles, and H. E. Brooks, 2012: Convective modes for significant severe thunderstorms in the contiguous United States. Part I: Storm classification and climatology. Wea. Forecasting, 27, 1114-1135, doi:10.1175/WAF-D-11-00115.1.

Tescon, J. J., T. T. Fujita, and R. F. Abbey Jr., 1983: Statistical analyses of U.S. tornadoes based on the geographic distribution of population, community, and other parameters. Proc. 13th Conf. on Severe Local Storms, Tulsa, OK, Amer. Meteor. Soc., 120-123.

Trapp, R. J., S. A. Tessendorf, E. S. Godfrey, and H. E. Brooks, 2005: Tornadoes from squall lines and bow echoes. Part I: Climatological distribution. Wea. Forecasting, 20, 23-34, doi:10.1175/WAF-835.1.

Twisdale, L. A., 1982: Regional tornado data base and error analysis. Proc. 12th Conf. on Severe Local Storms, San Antonio, TX, Amer. Meteor. Soc., 45-50.

Earth Interactions is published jointly by the American Meteorological Society, the American Geophysical Union, and the Association of American Geographers. Permission to use figures, tables, and brief excerpts from this journal in scientific and educational works is hereby granted provided that the source is acknowledged. Any use of material in this journal that is determined to be "fair use" under Section 107 or that satisfies the conditions specified in Section 108 of the U.S. Copyright Law (17 USC, as revised by P.IL. 94553 ) does not require the publishers' permission. For permission for any other from of copying, contact one of the copublishing societies. 